\title{
Mükemmeliyetçilik ile Yaşam Doyumu Arasındaki îlişkide Affetmenin Aracı Rolü ${ }^{1}$
}

\author{
Nesrin YANGIN* \\ Fatih CAMADAN ${ }^{* *}$
}

\begin{abstract}
Öz: Bu araştırmanın amacı, özel gereksinimli çocuğa sahip annelerin mükemmeliyetçilikleri ile yaşam doyumları arasındaki ilişkide affetmenin aracı rolünün olup olmadığının incelenmesidir. Araştırmanın çalışma grubunu, özel gereksinimli çocuğa sahip 404 anne oluşturmaktadır. Araştırmadaki sonuçlar şu şekildedir; özel gereksinimli çocuğa sahip annelerin olumsuz mükemmeliyetçilikleri, kendini affetme, başkalarını affetme, durumu affetme ve genel affetme davranışlarındaki değişimi olumsuz yönde; olumlu mükemmeliyetçilikleri ise kendini affetme, durumu affetme ve genel affetme davranışlarındaki değişimi olumlu yönde açıklamaktadır. Olumlu mükemmeliyetçilik yaşam doyumunu olumlu yönde; olumsuz mükemmeliyetçilik ise yaşam doyumunu olumsuz yönde açıklamaktadır. Kendini affetme, başkalarını affetme, durumu affetme ve genel affetme davranışları ise yaşam doyumlarını olumlu yönde açıklamaktadır. Ayrıca özel gereksinimli çocuğa sahip annelerin mükemmeliyetçilikleri ile yaşam doyumları arasındaki ilişkide affetmenin kısmi aracı değişken olarak rol oynadığ 1 belirlenmiştir.
\end{abstract}

Anahtar Sözcükler: Affetme, Özel Gereksinimli Çocuğa Sahip Anne, Mükemmeliyetçilik, Yaşam Doyumu

\section{The Mediating Role of Forgiveness in the Relationship Between Perfectionism and Life Satisfaction}

\begin{abstract}
This study sets out to examine the mediating role that forgiveness play in the relationship between perfectionism and life satisfaction for the mothers of children with special needs. Our study group consisted of 404 mothers who have children with special needs. Our findings reveal that perfectionist mothers in the negative sense are unable to forgive themselves, others, and their situation, as well as to forgive in general. Those who are perfectionists in the positive sense likewise have a more positive relationship with forgiveness. Positive perfectionists are more satisfied with their lives, while negative perfectionists are less satisfied with their lives. Mothers who are able to forgive get more satisfaction out of life. Just as importantly, our findings also show that forgiveness can partially mediate the relationship between perfectionism and life satisfaction for mothers of children with special needs.
\end{abstract}

Keywords: Forgiveness, Mother with a Child with Special Needs, Perfectionism, Life Satisfaction

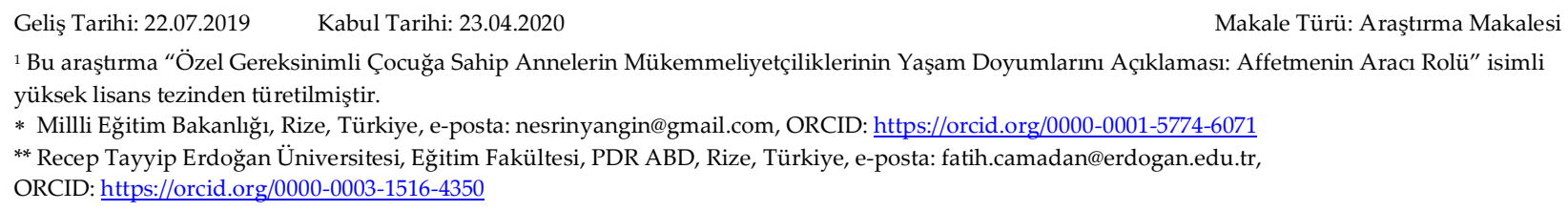

Geliş Tarihi: 22.07.2019 Kabul Tarihi: 23.04.2020 Makale Türü: Araştırma Makalesi

${ }^{1}$ Bu araştırma “Özel Gereksinimli Çocuğa Sahip Annelerin Mükemmeliyetçiliklerinin Yaşam Doyumlarını Açıklaması: Affetmenin Aracı Rolü” isimli yüksek lisans tezinden türetilmiştir.

* Millli Eğitim Bakanlığı, Rize, Türkiye, e-posta: nesrinyangin@gmail.com, ORCID: https://orcid.org/0000-0001-5774-6071

** Recep Tayyip Erdoğan Üniversitesi, Eğitim Fakültesi, PDR ABD, Rize, Türkiye, e-posta: fatih.camadan@erdogan.edu.tr, ORCID: https://orcid.org/0000-0003-1516-4350 
Yaşam doyumu, kişinin beklentileri ile ulaşmak istediği standartların karşılaştırılması sonucunda ortaya çıkan yargı olarak ifade edilmektedir. Bu noktada yaşam doyumunun öznel bir yanının olduğu belirtilmektedir. Bu çerçevede yaşam doyumu, bireyin elindekiler ile elde etmek istedikleri arasındakilerin karşılaştırılmasına bağlı olarak ortaya çıkan bir duygudur (Diener, Emmons, Larsen ve Griffin, 1985). Shin ve Johnson (1978) tarafından yaşam doyumu, bütün alanları düşünerek insanın yaşam kalitesine yönelik yine kendisince belirlenmiş olan ölçütlere dayanarak değerlendirmelerde bulunması olarak ifade edilmiştir. Farklı bir tanımda ise yaşam doyumu, insan hayatının bütün yönlerinin niteliğinin olumlu yönde gelişimi olarak tanımlanmıştır (Veenhoven, 1996). Bu bağlamda yaşam doyumunun, kişinin belli bir durumuna ilişkin tatmin oluşu değil; bütün yaşamı ile ilgili olduğu kabul edilmektedir (Avşaroğlu, Deniz ve Kahraman, 2005). Song ve Appleton'a (2008) göre yaşam doyumu altı öğeden oluşmaktadır. Bu öğeler; (1) bireyin gelir durumu, (2) işi ve sosyal konumu, (3) sahip oldukları, sahip olamadıkları ve sosyal dinamikliği, (4) refah koşulları, (5) dünya görüşü ve (6) ailesi ve sosyal ilişkileri şeklindedir. Diener'e (1984) göre ise yaşam doyumu bireylerin sahip oldukları yaşam koşullarına ve bireysel standartlarına dayanarak değişebilir dinamik bir yapıdır. Demirel ve Canat'a (2004) göre yaşam doyumunda hoşnutluğa etki eden bazı unsurlar bulunmaktadır. Bunların içinde özsaygının yaşam doyumundaki etkisinin önemli düzeyde olduğu vurgulanmaktadır. Ayrıca kişiye ait psikolojik durum, yaşam doyumuna ilişkin bir göstergedir. Kişisel hayatta karşılaşılabilecek bazı sorunlar, karşılaşılan güçlükler, bireysel ve sosyal çatışmalar yaşam doyumunda azalmaya neden olabilmektedir. Bu konuda yapılan araştırmalarda yaşam doyumunun depresyon (Headey, Kelley ve Wearing, 1993; Lee, Kim ve Oh, 2003), tükenmişlik (Ünal, Karlıdağ ve Yoloğlu, 2001), sürekli kayg1 (Gündoğar, Gül, Uskun, Demirci ve Keçeci, 2007), stres (Mahmoud, Staten, Hall ve Lennie, 2012) ve umutsuzluk (Akandere, Acar ve Baştuğ, 2009) gibi birtakım olumsuz psikolojik dinamiklerle negatif; öz-bakım (Altay ve Avc1, 2009), psikolojik sağlamlık (Beutel, Glaesmer, Wiltink, Marian ve Brähler, 2010; Ülker Tümlü ve Recepoğlu, 2013), azimli olmak (Singh ve Jha 2008) ve benlik saygisı (Çeçen, 2008; Leung ve Leung, 1992) gibi çeşitli olumlu psikolojik dinamikler ile ise olumlu yönde anlamlı ilişkisinin olduğu ortaya koyulmuştur.

Karşılaşılan kimi olumsuz durumlar insanların yaşam doyumlarını olumsuz yönde etkileyebilmektedir. Yaşam doyumu azalan birey, bir yandan kusursuz olma çabası ile hareket ederek kabul edilme ve değer görme gereksinimini gidermek üzere uğraşırken diğer taraftan da sevilme ve insanların kendisine kabul etme tepkisi vermeyeceğinden veya reddedileceğinden dolayı korku yaşayabilmektedirler. Bu gibi davranışlar ise bireyin hem hata yapmama durumunu iyice zorlaştırabilmekte hem de reddedilmesini kolay hale getirebilmektedir. $\mathrm{Bu}$ durumun sonucunda ise hata yapmak kişi için korku verici bir durum olarak algilanabilmekte ve birey hatalara karşı aşırı odaklanır hale gelebilmektedir (İmamoğlu ve Yavuz, 2011).

Kusursuz olma çabasını doğuştan getirilen eksiklik duygusu ile açıklayan bireysel psikoloji savunucularına göre tüm insanlar yaşamına eksiklik duygusu ile başlamaktadırlar. Eksiklik duygusu, bireyin kendini değerlendirirken yetersiz bir varlık olarak algılamasından ve buna eşlik eden kaygı gibi olumsuz duygulardan meydana gelmektedir (Yöntem, Öktem ve Artuç, 2017). Bir diğer önemli kavram olan üstünlük çabası ise kişiliğin temel özelliği olarak görülmektedir. Adler'e (2008) göre dünyaya gelmesiyle başlayan eksiklik duygularından kurtulma düşünceleriyle hareket eden birey, üstün olma çabası içine girerek bir yandan da mükemmel olmak için çalışmaya başlamaktadır. Kaya ve Peker (2016), aşırı bir şekilde kusursuz olma düşünceleri ile hareket eden bireyin beraberinde birtakım düşünceler geliştirebildiğini de öne sürmüştür. Bunlardan birisi de hayali bir üstünlük düzeyine ulaşma amacıyla bireyin aşırı çaba gösterme eğilimi içerisine girebilmesi durumudur. Buradan hareketle kişi abartılı amaçlar tasarlar ve bunları elde etmek için hatasız yöntemler geliştirmeye çalışır. Bu kişilerin yaşamlarında hatalara hiç yer yoktur ve hata yapmak onlar için korkunç bir şeydir.

Mükemmeliyetçilik, bireylerin günlük hayatlarında aşırı yüksek düzeyde ölçütler geliştirme ve yaptıkları yanlışlara odaklanarak yüksek kaygılar yaşama biçiminde farklı özelliklere sahip olma ile ilgili çok yönlü ve karmaşık bir kavram olarak açılanmaktadır (Jansson-Fröjmark ve Linton, 2007). Bu kapsamda mükemmeliyetçilik, bireylerin hayatlarında yüksek standartlar geliştirmeleri, bunlara çok yoğun biçimde odaklanmaları ve her yaşantıyı aşırı bir şekilde irdeleyerek sorgulayıcı biçimde sonuçlarını ele almalarını içermektedir (Craddock, Church, Harrison ve Sands, 2010). 
Çok yönlü ve karmaşık bir özellik olan mükemmeliyetçilik, yürütülen işlerde en iyisi olabilmek amacıyla olduğundan fazla düzeyde çaba sarf etme ile ilgili görülmektedir. Mükemmeliyetçilik, mükemmel olmanın olabilirliğine inanmak ile birlikte o duyguya ulaşabilmek için bireyin hem kendisi hem de çevresindekiler açısından yüksek düzeyde koşullar geliştirme eylemi şeklinde ifade edilmektedir (Flett ve Hewitt, 2002). Rice ve Mirzadeh (2000), mükemmeliyetçiliğin uyumlu (olumlu/sağlıklı/normal) ve uyumsuz (olumsuz/ sağlıksı/ nevrotik) olmak üzere iki formu olduğunu ifade etmektedir. Onlara göre uyumlu mükemmeliyetçiliğe sahip bireyler, sağlıklı ve normal bireylerin özelliklerini gösterirken; uyumsuz mükemmeliyetçiliğe sahip bireyler ise sağlıksız ve psikopatolojik davranışlar sergilemektedirler. Mükemmeliyetçiliğin olumlu olanının yüksek standartlar, uyum ve başarılı akademik performans ile ilgili olduğu savunulurken; olumsuzunun ise kişinin hayal kurmasına zarar verdiği, yeteneklerini kullanmasını engellediği, başarısızlık ve hata yapma korkusuna neden olduğu öne sürülmektedir.

İnsanlar yaşamını sürdürürken çeşitli nedenlerle çatışma ve anlaşmazlıklar yaşayabilmektedir (McCullough, 2001). Kurdukları etkileşimlerde mutluluk, doyum ve paylaşma gibi pozitif duygular hissetmekle birlikte kırılma, incinme ve gücenme gibi negatif duygular da yaşayabilmektedirler (ErgünerTekinalp ve Terzi, 2012). Bu da bireylerin yaşam doyumlarını etkileyebilmektedir. İnsanların birbirleri ile geliştirdikleri etkileşimlerinde oluşan olumsuz sonuçları engelleme ve iletişimi sürdürmeleri üzerinde affetmenin önemli bir rolünün olduğu düşünülmektedir. Uzun yıllar felsefede ve din bilimleri çerçevesinde ele alınmasıyla affetmenin, felsefi ve dini bir yapı olarak kavramsallaştığı görülmektedir. Bu bağlamda affetme hakkında ortaya koyulan açılamalar farklılık göstermesine rağmen Truong (1991) tarafından mevcut bakış açıları tümel biçimde üç kategoride toplanmıştır:

1. Affetme, Tanrısallığın doğasına katılma, inanç göstergesi ve ilahi bir güç tarafından uygulanan bir eylemdir.

2. Affetme, toplumsal ahlakın merkez mesajıdır. Diğer bir ifade ile insanın affetme davranışı, merhametli ve ahlaki bir davranıştır; ayrıca sosyal bir görev ve kişiler arası ilişkiyi yeniden kurmanın yoludur.

3. Başka insanlar ve Tanrı tarafından affedilmek için ya da acılardan kurtulabilmek için affetmek gerekir.

Affetme, bir irade işi ve bir affedici tutumu seçme davranışıdır. Bu, ne gitmesine izin verilen bir durum ya da kabullenme ne de kendisinden bağımsız olarak uygulanan doğadaki bir çalışmadır. Bu yüzden affetme ve affetme süreci duygu içerikli bir uygulama olarak görülmüştür (Murray, 2002). Affetme ve affedicilik geçmişten günümüze değin felsefi ve teolojik araştırmaların konusu olmakla birlikte psikolojide de affetme ile ilgili çalışmalar özellikle son yıllarda popülerlik kazanmıştır (Davis, Worthington, Hook ve Hill, 2013). Affetme ile ilgili yapılan araştırmalarda bu kavramın farklı yönlerden ele alındığı görülmektedir. Bu noktada özellikle kişinin kendini affetmesi, başkalarını affetmesi, duygusal ilişkileri affetme, Tanrı'nın insanları affetmesi ve ulusların birbirini affetmesi gibi çeşitli türlerinin olduğu ortaya koyulmuştur (Enright ve Coyle, 1998).

Kendini affetmeyi motivasyon değişikliği olarak ele alan araştırmacılardan Hall ve Fincham (2005), kendini affetmeyi suç konusuyla ilgili uyarıcılardan gittikçe daha az şekilde kaçmaya yarayacak biçimde motive olmayı, kendisine karşı intikam alma isteklerinin de azalmasıyla öz-yardımseverlik yönünde bir istek artışı şeklinde görmektedir. Kişilerarası ilişkilerde başkalarını affetme, bir kişi ile cansız bir nesne (Enright, Santos ve Al-Mabuk, 1989), doğa güçleri (Enright ve Group, 1996) ya da Tanrı (Enright, Gassin ve Wu, 1992) arasında değil de sadece insanlar arasında meydana gelen bir süreç olarak tanımlanmaktadır. Enright ve The Human Development Study Group (1994) ise başkalarını affetmeyi, merhamet (compassion), cömertlik (generosity), hatta sevgi gibi hak edilmeyen hislerin teşvik edilmesiyle, bireyin onu haksız yere inciten kişiye yönelik sinirlenme, olumsuz yargılama ve ilgisiz yönelim gibi durumlardan istençli biçimde vazgeçmesi olarak tanımlamaktadır. Genel olarak affetme ise kişinin kendisini kıran ve inciten birisine yönelik aslında hak etmediğini düşündüğü merhamet ve sevgiyi belirterek darılma, gücenme, intikam alma ve kin tutma gibi olumsuz tutum ve davranışlardan vazgeçme eğilimi olarak tanımlanmaktadır (Enright ve Coyle, 1998). 
Özel gereksinimli çocuğa sahip ailelerin yaşam doyumu, mükemmeliyetçilik ve affetme gibi özellikleri ile ilgili alanyazında henüz çok fazla incelemenin yapılmadığı öne sürülebilir. Zira bu özellikler ile ilgili olarak yapılan çalışmalar genel itibariyle özel gereksinime gerek duymayan çocuklar ve ebeveynlerine yönelik olarak gerçekleştirilmiştir (Bowman, 2001; Watson ve Keith, 2002). Bununla birlikte ilgili alanyazında çocukların günlük hayatlarını etkileyen, onunla fazlasıyla zaman geçiren ve öncelikli bakımını yürüten aile ferdinin özellikle anne olduğuna ilişkin bir uzlaşı bulunmaktadır (Brown, MacAdam-Crisp, Wang ve Iarocci, 2006). Özel gereksinimli çocuğa sahip anneler ile ilgili yapılan araştırmalarda ise bu kişilerin, zihinsel ve fiziksel güçlüklere yönelik oldukça savunmasız kaldıkları ve yaşam doyumlarının daha düşük olduğu öne sürülmektedir (Sipos, Predescu, Muresan ve Iftene, 2012).

Eğitmenlerin ve araştırmacıların asıl hedefleri, annelerin özel gereksinimli çocuğuna daha çok yardım edebilmesi amacıyla onların hem kendi bireysel hayatlarından hem de çocuğunun yaşamından daha fazla tatmin olmasına yardımcı olmaktır (Milgram ve Atzil, 1988). Bu durum özel gereksinimine göre destek eğitimi gören çocuklar kadar annelerinin de bu süreçte ihtiyaç duyduğu psikolojik öğeler üzerinde çalışmaların yürütülmesine gerek olduğu anlamına gelmektedir. Nitekim ailenin sahip olduğu genel yaşam doyumu; aile fertlerinin özellikle de annelerin gereksinimlerinin temin edilmesi, aile kimliğini yansıtan birlikte yaşam biçiminin kurulması, ailenin tüm üyeleri açısından önem arz eden amaçların elde edilmesi şeklinde ifade edilmektedir (Park, Turnbull ve Rutherford Turnbull, 2002). Küçüker (1993) ve Küllü'nün (2008) araştırmalarında özel gereksinimli çocukların diğer kardeşlerinde de uyum ve davranışsal güçlükler belirebildiği ve bu olumsuz durumların strese yönelik diğer etkenleri de aktif ederek anneleri mutsuzluğa itebildiği ileri sürülmüştür. Cin ve Kıllı̧’a (2005) göre ise özel gereksinimli çocuğa sahip anneler psikolojik ve sosyal desteğe, diğer annelerden daha fazla ihtiyaç duymaktadırlar. Bu noktada stres, kaygı ve depresyona bağlı olarak gelişen olumsuz duygular, annenin yaşam doyumunu ve affetme davranışını azaltabilmektedir. Bu kapsamda sunulan yardım ve destek hizmetleri annelerin olumsuz mükemmeliyetçilikleri ile kaygılarını azaltmada ve yaşam doyumları ile affetme davranışlarını arttırmada önemli bir etmendir (Cameron ve Armstrong, 1991; Cin, 2001; Ersoy ve Güneysu, 1998; Kaner, 2004; Tamer, 2010). Sunulan yardım ve destek hizmetleri, özel gereksinimli çocuğa sahip annelerin kendisi ve çocuğu hakkındaki düşünce, duygu ve beklentilerini, çocuğunu olduğu gibi kabul edebilmesini ve gelecekle ilgili umutlarını tekrar ve daha gerçekçi biçimde belirlemesini destekleyebilmektedir (Deniz, Dilmaç ve Arıcak, 2009; Ersanlı ve Kutlu, 1998).

İlgili literatür incelendiğinde affetme, mükemmeliyetçilik ve yaşam doyumu arasındaki ilişkiye ışık tutabilecek çeşitli araştırmaların olduğu görülmüştür. Mükemmeliyetçilik ile affetmeyi konu edinen araştırmalarda bu iki değişken arasında negatif yönlü ve anlamlı bir ilişkinin olduğu tespit edilmiştir (Bugay, 2010; Camadan ve Yazıc1, 2017; Kaya ve Peker, 2016; Kim, Johnson ve Ripley, 2011; Mistler, 2010). Mükemmeliyetçilik ile yaşam doyumu arasındaki ilişkilerin incelendiği araştırmalarda ise bu iki değişken arasında anlamlı ve negatif yönlü ilişkilerin (Karababa ve Acun Kapıkıran, 2014) yanı sıra anlamlı ve pozitif yönlü ilişkilerin de olduğu ortaya koyulmuştur (Çelik, Arıcı Özcan ve Turan, 2014; Uz Baş, 2011). Affetme ile yaşam doyumu arasındaki ilişkiye yönelik yapılan araştırmalarda ise bu iki değişken arasında olumlu yönlü ve anlamlı bir ilişkinin olduğu ortaya koyulmuştur (Thompson ve diğerleri, 2005; Topbaşoğlu Altan ve Çivitci, 2017).

İlgili literatürde mükemmeliyetçilik, affetme ve yaşam doyumu dışındaki çeşitli değişkenlerin özel gereksinimli çocuğa sahip ebeveynlerle ilişkisini ele alan araştırmalar incelendiğinde Güvendeğer Doksat, Balkanlı Zengin ve Doksat'ın (2018) hiperaktivite bozukluğu ve dikkat eksikliği tanısı almış bireylerin ebeveynlerinin, sosyal odaklı mükemmeliyetçilik ortalamaları ve toplam mükemmeliyetçilik ortalamalarının tanı almayan çocukların ebeveynlerinden daha yüksek olduğu tespit edilmiştir. Altuğ Özsoy, Özkahraman ve Çallı'nın (2006) yaptıkları çalışmada zihinsel engelliliği bulunan bireye sahip ebeveynlerin \%54,5'inin ileri zamana ilişkin kaygı yaşadıkları, \%48,2'sinin çocuğuna yönelik her zaman kaza geçirme ya da yaralanma korkusu hissettikleri tespit edilmiştir. Ayyıldız, Konuk Şener, Kulakçı ve Veren (2012) tarafından yapılan çalışmada engelliliği bulunan çocuklar ile ilgili olarak ebeveynlerin \%62,4'ünün çevresinin bakışından rahatsız olduğu, \%40,4'ünün çocuğunun engelli olmasından kendisini doğrudan suçlu hissettiği saptanmıştır. Yıldırım ve Conk'un (2005) yürüttükleri çalışmada engelliliği bulunan çocuğa sahip ailenin, çocuklarının 
engelliliğinden dolayı kendilerini suçlu hissettikleri ifade edilmektedir. Özcanarslan, Karataş ve Aydın'ın (2014) yaptıkları çalışmada ise engelli çocuğa sahip annelerin çoğunun orta ve ileri derecede depresyon yaşadıkları belirtilmiştir.

Yukarıda değinilen açıklamalardan hareketle özel gereksinimli çocuğa sahip annelerin çeşitli özelliklerinin yanında mükemmeliyetçilik, affetme ve yaşam doyumu gibi özelliklerinin de incelenmesinin hem annelerin hem de çocuklarının yaşantıları ile ilgili önemli çıkarımlarda bulunulmasına katkı sağlayacağı tahmin edilmektedir. Bu açıklamalar ışığında araştırma, özel gereksinimli çocuğa sahip annelerin mükemmeliyetçilikleri ve affetme davranışları arasındaki ilişkiyi tespit etmeyi ve bu iki değişkenin özel gereksinimli çocuğa sahip annelerin yaşam doyumlarını açıklayıp açıklamadığını ortaya koymayı amaçlamaktadır. Bu sayede özel gereksinimli çocuğa sahip annelerin davranışları ile ilgili önemli ipuçları elde edilebileceği düşünülmektedir.

\section{Araştırmanın Önemi}

Özel gereksinimli çocuğu olan annelerin, çocuklarının bu durumda olmasından dolayı kendilerini suçlayabildikleri bilinmektedir (Yıldırım ve Conk, 2005). Ayrıca bu annelerin kendilerinin ve çevresindekilerin mükemmel ve kusursuz olması gerektiğine dair düşünce yapıları da var ise bu gibi düşünceler, yaşam doyumlarını olumsuz yönde etkileyebilmektedir. Bu noktada affetme davranışı devreye girebilmektedir. Özel gereksinimli çocuğa sahip annelerin mükemmeliyetçiliklerini azaltan bir unsur olarak gerek kendilerine gerekse diğer insanlara yönelik affedici yönleri gelişebilirse yaşam doyumlarının da artacağı ön görülmektedir. Özel gereksinimli çocuğa sahip annelerle ilgili olarak yapılan çalışmalar incelendiğinde; yaşam doyumu, mükemmeliyetçilik ve affetme gibi psikolojik dinamiklerin birbiriyle olan ilişkisinin ele alındığı herhangi bir araştırmaya rastlanmamıştır. Bu kapsamda mükemmeliyetçiliğin affetme ve/veya yaşam doyumu üzerine bütüncül etkisinin ele alındığı bir çalışma bulunmamakla birlikte özel gereksinimli çocuğa sahip anneler ile ilgili de bu yönde bir çalışma ile karşılaşılmamıştır. Bunun yanında yine yaşam doyumu üzerinde etkisinin olabileceği düşünülen mükemmeliyetçiliğin özellikle affetmenin aracılık etkisi ile sınanmasını ele alan bir araştırma da literatürde mevcut değildir. Diğer bir husus, bu çalışmada özel gereksinimli çocuğa sahip anneler üzerinde incelemenin yapılmasıdır. Bunun nedeni, annelerin özel gereksinimli çocukları ile daha yakın bağlar kurmaları ve çocuklarının gelişiminde kendilerinin önemli rol ve sorumluluklarının olduğunun düşünülmesidir. Nitekim gerek özel gereksinimli gerekse normal özelliklere sahip çocuklar, büyüdükleri yıllar boyunca annelerinin ebeveynlik stillerinin ve kişilik özelliklerinin etkisi altındadırlar. Bununla birlikte annelerin mükemmeliyetçiliklerinin, affetme davranışlarını ve yaşam doyumların etkileyebileceği gibi özel gereksinimli çocuklarının yaşantıları üzerinde de etkisinin olabileceği düşünülmektedir. Bu bağlamda özel gereksinimli çocuğa sahip annelerin mükemmeliyetçilik, affetme ve yaşam doyumlarının bütüncül biçimde incelenmesi hem annelerin hem de özel gereksinimli çocuklarının yaşantıları ile ilgili sonuçlar ortaya koyacağından önemli görülmüştür.

\section{Araştırmanın Amacı}

$\mathrm{Bu}$ araştırmanın amacı, özel gereksinimli çocuğa sahip annelerin mükemmeliyetçilikleri ile yaşam doyumları arasındaki ilişkide affetmenin aracı rolünün olup olmadığının belirlenmesidir. Bu temel amaç doğrultusunda aşağıdaki sorulara yanıt aranmaya çalışılmıştır.

1. Özel gereksinimli çocuğa sahip annelerin mükemmeliyetçilikleri ve affetme davranışları, yaşam doyumlarını anlamlı bir biçimde yordamakta mıdır?

2. Özel gereksinimli çocuğa sahip annelerin mükemmeliyetçilikleri ile yaşam doyumları arasındaki ilişkide affetmenin aracı bir rolü bulunmakta mıdır?

\section{Yöntem}

Bu bölümde araştırmanın modeli, çalışma grubu, veri toplama araçları, verilerin toplanması ve analizine yer verilmiştir. 


\section{Araştırmanın Modeli}

$\mathrm{Bu}$ araştırmada özel gereksinimli çocuğa sahip annelerin mükemmeliyetçilikleri ile yaşam doyumları arasındaki ilişkide affetmenin aracı rolünün olup olmadığı belirlenmeye çalışılmıştır. Bu amaca ulaşılmasında araştırmanın modeli, araştırmacının müdahalesi olmaksızın bir ya da birden fazla durumu olduğu haliyle tasvir etmeyi amaçlayan betimsel taramaya dayandırılmıştır. Araştırmada özel gereksinimli çocuğa sahip annelerin mükemmeliyetçilikleri bağımsız değişken; yaşam doyumları bağımlı değişken, affetme ise aracı değişken olarak belirlenmiştir. Araştırma kapsamında incelenecek olan değişkenler arasındaki ilişkilere yönelik olarak Şekil 1'de sunulan modeller oluşturulmuştur.

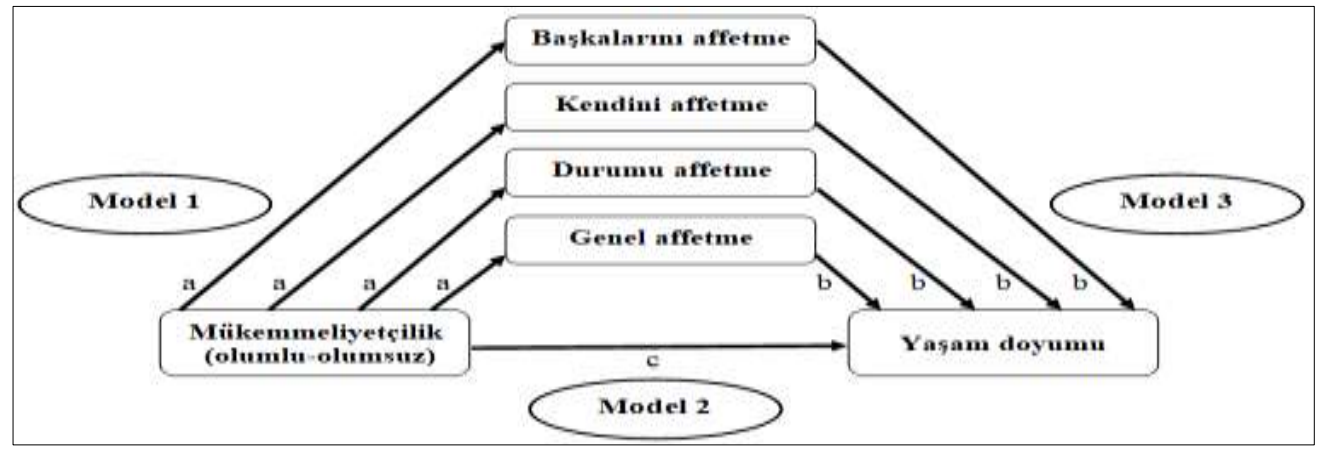

Şekil 1. Değişkenler arasındaki ilişkilere yönelik olarak oluşturulan modeller

\section{Çalışma Grubu}

Araştırmanın çalışma grubunu Rize ilinde faaliyet gösteren bir özel eğitim ve rehabilitasyon merkezinde eğitim desteği gören özel gereksinimli çocuğa sahip anneler oluşturmaktadır. Rize ilinde yer alan tüm özel eğitim ve rehabilitasyon merkezlerinde eğitim desteği gören özel gereksinimli çocuğa sahip annelerin tamamına ulaşmanın zor olacağı anlaşılmıştır. Bu doğrultuda emek, zaman, maliyet ve ulaşılabilirlik açısından kolaylık sağlayacağı düşünülerek uygulamalar, araştırmacılardan birinin görev yaptığı kurumda gerçekleştirilmiştir. Araştırma kapsamında özel gereksinimli çocuğu olan toplam 428 anneye ölçme araçları uygulanmıştır. Ancak büyük bir bölümünün eksik doldurulduğu görülen 24 katılımcının yanıtları çalışmadan çıkarılmış ve sonuçta 404 katılımcının yanıtları analizlere dâhil edilmiştir. Çalışma grubuna ilişkin birtakım demografik bilgiler Tablo 1'de sunulmuştur.

\section{Tablo I}

Çalışma Grubuna İlişkin Demografik Bilgiler

\begin{tabular}{|c|c|c|}
\hline Demografik Değişken & $\mathrm{f}$ & $\%$ \\
\hline \multicolumn{3}{|l|}{ Yerleşim Yeri } \\
\hline İl Merkezi & 215 & 53,20 \\
\hline İlçe Merkezi & 133 & 32,90 \\
\hline Köy & 56 & 13,90 \\
\hline \multicolumn{3}{|l|}{ Eğitim Durumu } \\
\hline Okuryazar & 12 & 3 \\
\hline İlkokul mezunu & 159 & 39,40 \\
\hline Ortaokul mezunu & 47 & 11,60 \\
\hline Lise mezunu & 125 & 30,90 \\
\hline Üniversite mezunu & 61 & 15,10 \\
\hline \multicolumn{3}{|l|}{ Yaş } \\
\hline 20-30 yaş & 37 & 9,20 \\
\hline $31-40$ yaş & 195 & 48,30 \\
\hline $41-50$ yaş & 158 & 39,10 \\
\hline 51 ve daha fazla yaş & 14 & 3,50 \\
\hline \multicolumn{3}{|l|}{ Çocuğun Engel Derecesi } \\
\hline Hafif düzey & 126 & 31,20 \\
\hline Orta düzey & 168 & 41,60 \\
\hline Ağır düzey & 110 & 27,20 \\
\hline Toplam & 404 & 100,00 \\
\hline
\end{tabular}




\section{Veri Toplama Araçları}

Verilerin toplanması için araştırmada kişisel bilgi formu ve araştırmanın değişkenlerinin ölçülmesine yönelik üç adet ölçme aracı kullanılmıştır. Bu araçlara ilişkin açıklamalar aşağıda sunulmuştur.

Kişisel bilgi formu. Özel gereksinimli çocuğa sahip annelerin demografik bilgilerine ulaşmak için araştırmacı tarafından düzenlenen kişisel bilgi formu uygulanmıştır. Bu formda annelerin yerleşim yeri, eğitim durumu, yaşı ve çocuğun engel derecesi hakkında bilgiler yer almıştır.

Heartland affetme ölçeği. Bu araştırmada Thompson ve diğerlerinin (2005) bireylerin affetme eğilimlerini ölçmek amacıyla geliştirdikleri ve Türkçe' ye Bugay ve Demir (2010) tarafından uyarlanan ölçek kullanılmıştır. Bu ölçek, 7'li Likert tipi olup 18 maddeden oluşmaktadır. Ölçekte kendini affetme, başkalarını affetme ve durumu affetme şeklinde üç alt boyut yer almaktadır. Ölçekte yer alan 2, 4, 6, 7, 9, 11, 13, 15 ve 17. maddeler ters çevrilerek puanlanmaktadır. İlk altı madde (1-6) kendini affetme, ikinci altı madde (7-12) başkalarını affetme, son altı madde (13-18) durumu affetme alt boyutunu oluşturmaktadır. Her bir alt boyutun toplam puanı 1 ile 42 arasında değişmektedir. Ayrıca ölçeğin toplam puanı da hesaplanabilmektedir. Puanın yükselmesi affetme eğiliminin de yükseldiği anlamına gelmektedir. Ölçme aracının Türkçe versiyonunun Cronbach alfa katsayısı kendini affetme için ,64, başkalarını affetme için ,79, durumu affetme için ,76 ve genel affetme için ,81 şeklinde hesaplanmıştır. Bu çalışmanın ardından Bugay, Demir ve Delevi (2012) farklı bir örneklemde, daha fazla birey üzerinde ölçme aracının psikometrik özelliklerini inceleyerek başlangıçtaki üç boyutlu yapının Türkiye örneklemi açısından uygunluğunu da test etmişler ve bu kapsamda doğrulayıcı faktör analizine ilişkin uyum değerlerini yeterli (GFI=,90, AGFI=,90, RMSEA=,10) düzeyde bulmuşlardır.

Olumlu-olumsuz mükemmeliyetçilik ölçeği. Bu çalışmada bireylerin mükemmeliyetçiliklerinin belirlenmesinde Kırdök (2004) tarafından geliştirilen ölçek kullanılmıştır. Bu ölçme aracındaki her ifade, dörtlü Likert tipi (1=Hiç uygun değil, 2=Uygun değil, 3=Uygun, 4=Tamamen uygun) şeklinde derecelendirilmiştir. Ölçme aracının olumlu mükemmeliyetçilik alt boyutundan (10 madde; 1, 3, 5, 6, 7, 9, 11, 12, 14, 16) alınabilecek puan 10 ile 40 arasında; olumsuz mükemmeliyetçilik alt boyutundan (7 madde; 2, 4, 8, $10,13,15,17)$ alınabilecek puan ise 7 ile 28 arasındadır. Ölçme aracının olumlu ve olumsuz olmak üzere oluşturulan iki alt boyutundan alınan puanlar arttıkça o alt boyuttaki mükemmeliyetçilik düzeyinin de arttığ ifade edilmiştir. Ancak ölçme aracında genel toplam puan hesaplanmamaktadır. Açımlayıcı faktör analizi sonucuna göre ölçme aracında 17 madde ve iki faktörlü bir yapının olduğu ileri sürülmüştür. Olumlu mükemmeliyetçilik olarak isimlendirilen birinci faktörde yer alan 10 maddenin faktör yükü ,47 ile ,64 arasındadır; özdeğeri 3,10'dur ve varyansın \%18,22'si açıklanmaktadır. Olumsuz mükemmeliyetçilik olarak isimlendirilen ikinci faktörde bulunan 7 maddenin faktör yükü ,52 ile ,64 arasındadır; özdeğeri 2,43'tür ve varyansın \%14,22'si açıklanmaktadır. Yapılan doğrulayıcı faktör analizi sonucunda değinilen iki faktörlü yapı doğrulanmıştır. Olumlu mükemmeliyetçilik boyutunun Cronbach alfa katsayısı ,81 olup; madde toplam puan korelasyonları ise ,43 ile ,55 arasında değişmektedir. Olumsuz mükemmeliyetçilik boyutunun Cronbach alfa katsayısı ,78 olup, madde toplam puan korelasyonları ise ,48 ile ,55 arasında değişim göstermektedir.

Yaşam doyumu ölçeği. Bu araştırmada kullanılan Diener ve diğerleri (1985) tarafından genel yaşam doyumunu ölçmek için geliştirilen ölçme aracının Türkçeye uyarlaması Dağlı ve Baysal (2016) tarafından yapılmıştır. Ölçeğe verilecek cevaplar, "Hiç katılmıyorum"dan "Tamamen katılıyorum"a kadar farklılaşacak şekilde 7'li Likert tipinde düzenlenmiştir. Ölçek beş maddeden oluşmaktadır. Dolayısıyla her bir ifadeden alınan puan 1-7, toplam puan ise 1 ile 35 arasında yer almaktadır. Ölçme aracından elde edilen puanın yükselmesi, yaşam doyumunun arttığını göstermektedir. Ölçme aracının uyarlamasının yapıldığı araştırmada ölçeğin bütünü için hesaplanan Cronbach Alpha iç tutarlık katsayısı ,88 olarak hesaplanmıştır. Ölçeğin testtekrar test güvenirliğini sınamak için yapılan iki uygulama arasındaki korelasyon katsayısı r=,97 olarak saptanmıştır. Ölçeğin yapı geçerliğini irdelemek amacıyla doğrulayıcı faktör analizi yapılmış ve sonuçta ölçeği meydana getiren ifadelerin dağılımı, orijinal ölçeğin dağılımını doğrulamıştır. 


\section{Veri Toplama ve Araştırmada İzlenen Etik İlkeler}

Araştırmada kullanılmaya karar verilen ölçme araçlarının bu çalışmada uygulanabilmesi için öncelikle bu ölçme araçlarını hazırlayan araştırmacılardan e-mail yolu ile ilgili izinler alınmıştır. Bunun yanında çalışmanın uygulandığı özel eğitim ve rehabilitasyon merkezinden de gerekli izin alınarak çalışma yürütülmüştür. Çalışmaya katılan annelerin gönüllü biçimde katılımının sağlandığına ilişkin bir form hazırlanmış, iki örnek çoğaltılarak biri anneye teslim edilmiş, diğeri araştırmacıda kalmıştır. Ayrıca katılımcılara sundukları kişisel bilgilerin hiçbir şekilde herhangi bir yerde kullanılmayacağının güvencesi verilmiştir. Dolayısıyla verilerin toplanmasında gizliliğe ve gönüllülüğe bağlı kalınmıştır. Araştırmacı çalışmayı yürüttüğü kurumda görev yaptığından ölçme araçları katılımcılara yüz yüze olacak şekilde doğrudan araştırmacı tarafından uygulanmıştır. Araştırmanın başlangıcında babaların da çalışmaya dâhil edilmek istenmesi fikri onların tümüyle gönülsüz olmasından dolayı sadece anneler ile yürütülmesi şeklinde değiştirilmiştir. Her bir anne için ölçme aracının uygulanması, ortalama 15-20 dakika kadar sürmüştür.

\section{Verilerin Analizi}

Araştırmanın temel amacı olan özel gereksinimli çocuğa sahip annelerin mükemmeliyetçilikleri ile yaşam doyumları arasındaki ilişkide affetmenin aracı rolünün olup olmadığının belirlenmesinde çoklu doğrusal regresyon analizi kullanılmıştır. Çoklu doğrusal regresyon analizinin yapılabilmesi için öncelikle birtakım varsayımların sağlanıp sağlanmadığı sınanmıştır. Bu amaçla tekli normallik, çoklu normallik, örneklem büyüklüğü, çoklu bağlantı problemi (multi-colinearity) ve doğrusallık varsayımları test edilmiştir (Pallant, 2015). Ayrıca araştırmada Pearson korelasyon analizi ve Sobel testine başvurulmuştur. Bu istatistiki tekniklerin kullanımı için SPSS 20.00 paket programından yararlanılmıştır.

\section{Bulgular}

\section{Betimsel İstatistiki Değerler}

Bu bölümde, araştırmanın temel amacı olan mükemmeliyetçilik ile yaşam doyumu arasındaki ilişkide affetmenin aracı rolünün olup olmadığını belirlemeden önce üç değişken arasındaki korelasyon katsayıları hesaplanmış ve elde edilen sonuçlar Tablo 2' de sunulmuştur.

Tablo II

Özel Gereksinimli Çocuğa Sahip Annelerin Yaşam Doyumu, Mükemmeliyetçilik ve Affetme Davranışları Arasındaki İlişkiler ve Birtakım Betimsel Istatistiki Değerler

\begin{tabular}{|c|c|c|c|c|c|c|c|c|c|c|}
\hline Değişkenler & $\mathbf{N}$ & $\bar{x}$ & sd & 1 & 2 & 3 & 4 & 5 & 6 & 7 \\
\hline Yaşam doyumu (1) & 404 & 21,48 & 7,41 & 1 & & & & & & \\
\hline Olumlu mükemmeliyetçilik (2) & 404 & 33,20 & 6,51 & $27^{* *}$ & 1 & & & & & \\
\hline Olumsuz mükemmeliyetçilik (3) & 404 & 16,76 & 5,32 &,$- 15^{* *}$ &,$- 40^{* *}$ & 1 & & & & \\
\hline Kendini affetme (4) & 404 & 27,51 & 7,37 & $25^{* *}$ &, $08^{*}$ &,$- 31^{* *}$ & 1 & & & \\
\hline Başkalarını affetme (5) & 404 & 27,14 & 8,26 & $28^{* *}$ &, 05 &,$- 12^{* *}$ &, $39^{* *}$ & 1 & & \\
\hline Durumu affetme (6) & 404 & 28,54 & 7,23 & $34^{* *}$ & $08^{*}$ &,$- 32^{* *}$ & $60^{* *}$ & $67^{* *}$ & 1 & \\
\hline Genel Affetme (7) & 404 & 83,20 & 19,16 &, $34^{* *}$ &, $08^{*}$ &,$- 30^{* *}$ &, $78^{* *}$ &, $83^{* *}$ &, $87^{* *}$ & 1 \\
\hline
\end{tabular}

" $\mathrm{p}<.05, " * \mathrm{p}<.01$

Tablo 2 incelendiğinde değişkenler arasındaki korelasyon katsayılarının -,05 ile ,87 arasında değiştiği ve değişkenler arasında birtakım anlamlı ilişkilerin olduğu gibi istatistiki olarak anlamlı olmayan ilişkilerin de olduğu görülebilmektedir. Sonuç olarak elde edilen veriler, değişkenler arasında çoklu bağlantı sorununun olmadığını göstermektedir.

\section{Mükemmeliyetçilik ve Affetmenin Yaşam Doyumunu Yordama Durumu}

Araştırmanın birinci alt amacı olan; özel gereksinimli çocuğa sahip annelerin mükemmeliyetçilikleri ve affetme davranışlarının, yaşam doyumlarını anlamlı biçimde yordayıp yordamadığının incelenmesinde çoklu doğrusal regresyon analizi gerçekleştirilmiştir. Çoklu doğrusal regresyon analizinin yapılabilmesi için öncelikle birtakım varsayımların (tekli normallik, çoklu normallik, örneklem büyüklüğü, çoklu bağlantı problemi (multi-colinearity) ve doğrusallık) sağlanıp sağlanmadığı kontrol edilmiştir. Yapılan analizler 
sonucunda değinilen varsayımların sağlandığı anlaşılmıştır. Bu aşamadan sonra araştırmanın bağımlı değişkeni olan yaşam doyumunu, bağımsız değişkenleri olan olumlu ve olumsuz mükemmeliyetçilik ve affetmenin her bir alt boyutunun ve genelinin ne şekilde yordadığı belirlenmeye çalışılmıştır. Bu amaçla gerçekleştirilen çoklu doğrusal regresyon analizi sonuçları Tablo 3'te sunulmuştur.

\section{Tablo III}

Mükemmeliyetçilik ve Affetmenin Yaşam Doyumunu Ne Şekilde Yordadığının Belirlenmesine Yönelik Yapılan Çoklu Doğrusal Regresyon Analizi

\begin{tabular}{|c|c|c|c|c|c|c|c|c|c|c|c|}
\hline \multirow{8}{*}{ 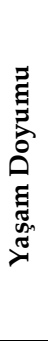 } & Bağımsız değişkenler & B & $\begin{array}{l}\text { Std. } \\
\text { Hata }\end{array}$ & $\beta$ & $\mathbf{t}$ & $\mathrm{p}$ & $\begin{array}{c}\text { İkili } \\
\mathbf{r}\end{array}$ & $\begin{array}{c}\text { Kismi } \\
\mathrm{r}\end{array}$ & TV & VIF & Durbin Watson \\
\hline & Sabit & 8,220 & 2,655 & & 3,096 & $002^{* *}$ & & & & & \\
\hline & Olumlu Mükemmeliyetçilik & 288 & 087 &, 324 & 3,023 & $003^{* *}$ & 274 & ,128 & ,789 & 1,316 & \multirow{6}{*}{2,061} \\
\hline & Olumsuz Mükemmeliyetçilik &,- 242 & ,074 & -261 & $-2,157$ & , $036^{*}$ &,- 153 &,- 090 & ,725 & 1,267 & \\
\hline & Kendini Affetme & ,215 & 072 & 282 & 2,663 & $012^{*}$ & ,253 & 051 & 601 & 1,414 & \\
\hline & Başkalarını Affetme & 243 & 063 & 284 & 1,811 &, $007^{* *}$ & 284 & 079 & 625 & 1,920 & \\
\hline & Durumu Affetme & 390 & ,126 & 424 & 3,742 & $001^{* *}$ & 342 & ,142 & 354 & 2,153 & \\
\hline & $\begin{array}{lll}\mathrm{R}=, 392 & \mathrm{R}^{2}=, 149 & \mathrm{~F}(5,398)=12,688\end{array}$ & $8 \quad \mathrm{p}<$ & & & & & & & & & \\
\hline
\end{tabular}

Tablo 3'te yer alan çoklu doğrusal regresyon analizi sonucunda; olumlu mükemmeliyetçilik, olumsuz mükemmeliyetçilik, kendini affetme, başkalarını affetme ve durumu affetme değişkenlerinin birlikte, yaşam doyumu ile anlamlı bir ilişki içinde oldukları ve söz konusu değişkenlerin birlikte yaşam doyumundaki değişimin \% 15'ini açıkladığ belirlenmiştir $\left(R=, 392 ; R^{2}=, 149 ; F_{(5,398)}=12,68 ; p<, 001\right)$. Standartlaştırılmış regresyon katsayılarına göre yordayıcı değişkenlerin yaşam doyumu üzerindeki göreli önem sırası, durumu affetme $(\beta=, 424 ; p<, 01)$, olumlu mükemmeliyetçilik $(\beta=, 324 ; p<.01)$, başkalarını affetme $(\beta=, 284 ; p<, 01)$, kendini affetme $(\beta=, 282 ; p<, 05)$ ve olumsuz mükemmeliyetçilik $(\beta=-, 261 ; p<, 05)$ şeklindedir. Bu sonuçlar ışığında bağımsız değişkenlerin tamamının bağımlı değişkeni anlamlı şekilde açıkladığı anlaşılmıştır.

\section{Mükemmeliyetçilik ve Yaşam Doyumu Arasındaki İlişkide Affetmenin Aracı Rolü}

Araştırmanın ikinci alt amacı olan; özel gereksinimli çocuğa sahip annelerin mükemmeliyetçilikleri ile yaşam doyumları arasındaki ilişkide affetmenin aracı rolünün olup olmadığı Baron ve Kenny'nin (1986) ortaya koyduğu işlem basamakları takip edilerek incelenmiştir. Bu basamaklar şu şekilde açıklanmıştır: (a) bağımsız değişkenin düzeyindeki değişimlerin, varsayılan aracı değişkendeki değişimleri açıklaması gerekir, (b) aracı değişkendeki değişimler bağımlı değişkendeki değişimleri açılamalıdır ve (c) a ve b durumları kontrol edildiğinde bağımsız değişkenin bağımlı değişkeni açıklama durumu ortadan kalkıyorsa aracı değişken tam aracılık; açıklama durumunda azalma gerçekleşiyorsa aracı değişken kısmi aracı olarak kabul edilmektedir.

Olumsuz mükemmeliyetçiliğin yaşam doyumunu açılamasında kendini affetmenin aracı rolünün olup olmadığının belirlenmesinde ilk aşama olarak yapılan çoklu doğrusal regresyon analizine göre olumsuz mükemmeliyetçiliğin kendini affetmeyi anlamlı düzeyde yordadığ $1\left(R^{2}=, 052, t(403)=-6,77 ; p<, 01 ; \beta=-, 24\right)$ ve kendini affetmenin de yaşam doyumunu anlamlı şekilde yordadığ 1 elde edilmiştir $\left(R^{2}=, 142 ; t(403)=8,33 ; p<, 01\right.$; $\beta=$,28). Çoklu doğrusal regresyon analizi ile ulaşılan bu bulgular, aracılık testi için gerekli olan koşulların sağlandığını göstermiştir. Yapılan analiz sonucunda belirlenen aracılık etkisi Şekil 2' de sunulmuştur.

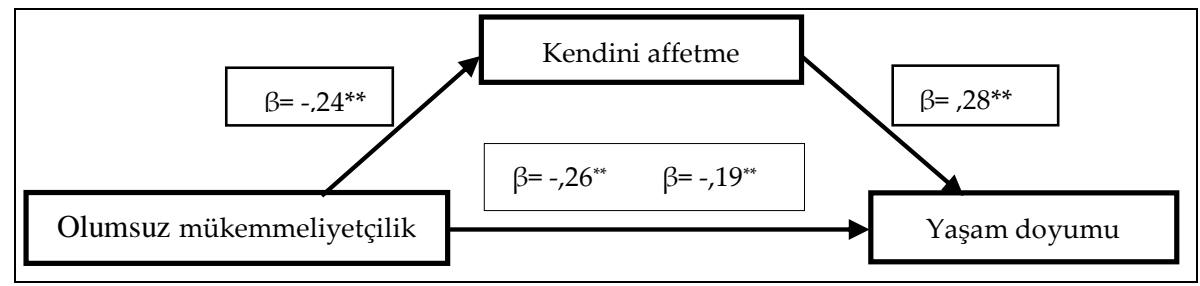

Şekil 2. Özel gereksinimli Çocuğa Sahip Annelerin Olumsuz Mükemmeliyetçilikleri ile Yaşam Doyumları Arasındaki İlişkide Kendini Affetmenin Aracı Rolüne İlişkin Beta Katsayıları

Şekil 2'ye göre olumsuz mükemmeliyetçiliğin yaşam doyumunu açıklamasına ilişkin hesaplanan beta ( $\beta$ ) katsayısı 26 iken; kendini affetme modele dahil edildiğinde ,19’a gerilemiştir. Beta $(\beta)$ değerindeki bu 
azalmanın anlamlı olup olmadığının belirlenmesi Sobel testi ile incelenmiştir. Yapılan analiz sonucunda kendini affetmenin aracılık etkisinin anlamlı olduğu bulunmuştur $(z=-5,25 ; p<, 01)$. Sonuç olarak, olumsuz mükemmeliyetçilik ile yaşam doyumu arasındaki ilişkide kendini affetmenin kısmi aracı rolünün olduğu belirlenmiştir.

Olumsuz mükemmeliyetçiliğin yaşam doyumunu açıklamasında başkalarını affetmenin aracı rolünün olup olmadığının belirlenmesinde ilk aşama olarak yapılan çoklu doğrusal regresyon analizine göre olumsuz mükemmeliyetçiliğin başkalarını affetmeyi anlamlı şekilde yordadığı $\left(R^{2}=, 016 ; t_{(403)}=22,485 ; p<, 01 ; \beta=-, 12\right)$ ve başkalarını affetmenin de yaşam doyumunu anlamlı düzeyde yordadığ $\left(R^{2}=, 084 ; t_{(403)}=12,011 ; p<, 01 ; \beta=, 28\right)$ belirlenmiştir. Çoklu doğrusal regresyon analizi ile ulaşılan bu bulgular, aracılık testi için gerekli olan koşulların sağlandığını göstermiştir. Yapılan analiz sonucunda belirlenen aracılık etkisi Şekil 3'te verilmiştir.

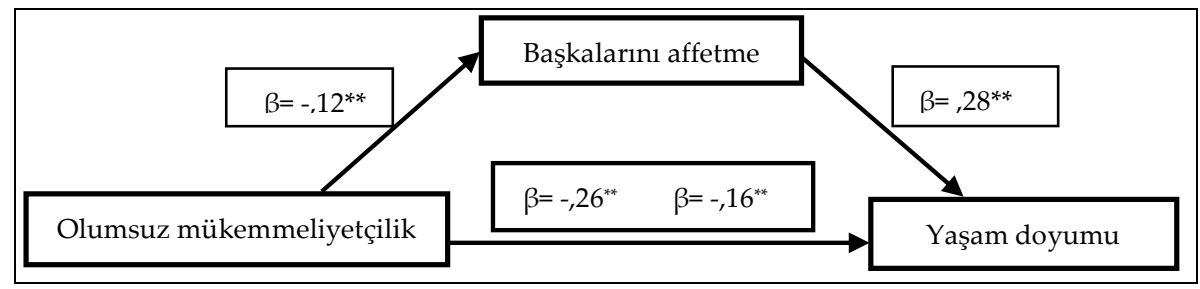

Şekil 3. Özel Gereksinimli Çocuğa Sahip Annelerin Olumsuz Mükemmeliyetçilikleri ile Yaşam Doyumları Arasındaki İlişkide Başkalarını Affetmenin Aracı Rolüne İlişkin Beta Katsayıları

Şekil 3'e göre olumsuz mükemmeliyetçiliğin yaşam doyumunu açıklamasına ilişkin hesaplanan beta ( $\beta$ ) katsayısı -,26 iken; başkalarını affetme modele dâhil edildiğinde -,16' ya gerilemiştir. Beta $(\beta)$ değerindeki bu azalmanın anlamlı olup olmadığının belirlenmesi Sobel testi ile incelenmiştir. Yapılan analiz sonucunda başkalarını affetmenin aracılık etkisinin anlamlı olduğu bulunmuştur $(\mathrm{z}=-2,11 ; \mathrm{p}<, 01)$. Sonuç olarak, olumsuz mükemmeliyetçilik ile yaşam doyumu arasındaki ilişkide başkalarını affetmenin kısmi aracı rolünün olduğu belirlenmiştir.

Olumsuz mükemmeliyetçiliğin yaşam doyumunu açılamasında durumu affetmenin aracı rolünün olup olmadığının belirlenmesinde ilk aşama olarak yapılan çoklu doğrusal regresyon analizine göre olumsuz mükemmeliyetçiliğin durumu affetmeyi anlamlı düzeyde açıladığ $\left(R^{2}=, 107 ; t t_{(403)}=31,924 ; p<, 01 ; \beta=-, 32\right)$ ve durumu affetmenin de yaşam doyumunu anlamlı şekilde açılladığ $\left(R^{2}=, 117 ; t_{(403)}=8,123 ; p<, 01 ; \beta=, 42\right)$ saptanmıştır. Çoklu doğrusal regresyon analizi ile ulaşılan bu bulgular, aracılık testi için gerekli olan koşulların sağlandığını göstermiştir. Yapılan analiz sonucunda belirlenen aracılık etkisi Şekil 4'te sunulmuştur.

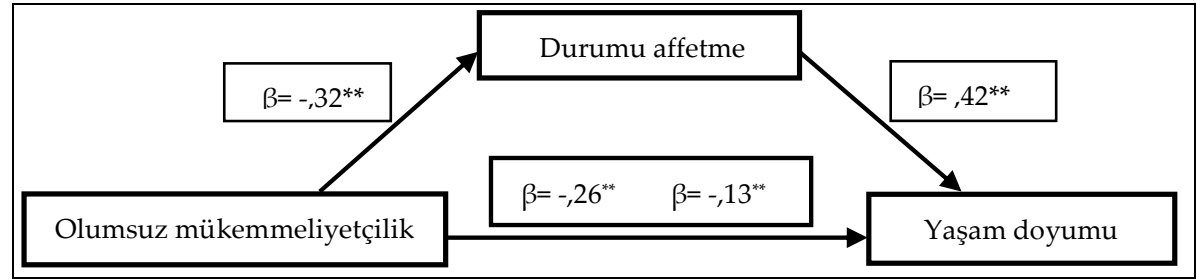

Şekil 4. Özel Gereksinimli Çocuğa Sahip Annelerin Olumsuz Mükemmeliyetçilikleri ile Yaşam Doyumları Arasındaki İlişkide Durumu Affetmenin Aracı Rolüne İlişkin Beta Katsayıları

Şekil 4'e göre olumsuz mükemmeliyetçiliğin yaşam doyumunu açıklamasına ilişkin hesaplanan beta $(\beta)$ katsayısı -,26 iken; kendini affetme modele dâhil edildiğinde -,13'e gerilemiştir. Ulaşılan sonuçlardaki beta ( $\beta$ ) değerindeki azalmanın anlamlı olup olmadığının belirlenmesi Sobel testi ile yapılmıştır. Yapılan analiz sonucunda durumu affetmenin aracılık etkisinin anlamlı olduğu bulunmuştur ( $\mathrm{z}=-7,87 ; \mathrm{p}<, 01)$. Sonuç olarak, olumsuz mükemmeliyetçilik ile yaşam doyumu arasındaki ilişkide durumu affetmenin kısmi aracı rolünün olduğu belirlenmiştir.

Olumsuz mükemmeliyetçiliğin yaşam doyumunu açılamasında genel affetmenin aracı rolünün olup olmadığının belirlenmesinde ilk aşama olarak yapılan çoklu doğrusal regresyon analizine göre olumsuz mükemmeliyetçiliğin genel affetmeyi anlamlı düzeyde yordadığ $\left(R^{2}=, 090 ; t_{(403)}=33,625 ; p<, 01 ; \beta=-, 30\right)$ ve genel 
affetmenin de yaşam doyumunu anlamlı şekilde yordadığı elde edilmiştir $\left(R^{2}=, 121 ; t_{(403)}=6,676 ; p<, 01 ; \beta=, 34\right)$. Çoklu doğrusal regresyon analizi ile ulaşılan bu bulgular, aracılık testi için gerekli olan koşulların sağlandığını göstermiştir. Yapılan analiz sonucunda belirlenen aracılık etkisi Şekil 5'te sunulmuştur.

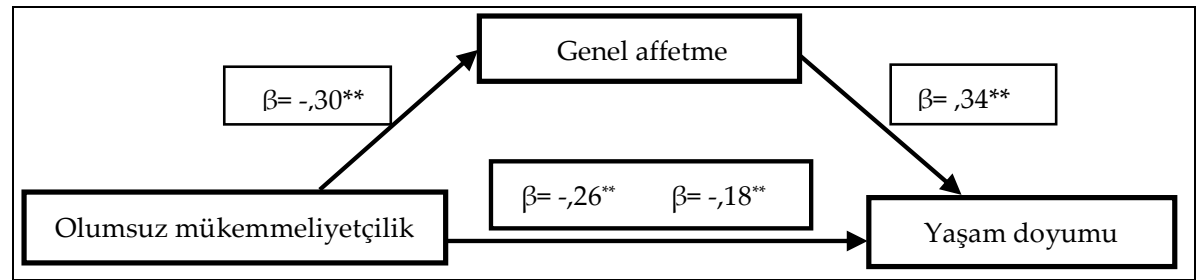

Şekil 5. Özel Gereksinimli Çocuğa Sahip Annelerin Olumsuz Mükemmeliyetçilikleri ile Yaşam Doyumları Arasındaki İlişkide Genel Affetmenin Aracı Rolüne İlişkin Beta Katsayıları

Şekil 5'e göre olumsuz mükemmeliyetçiliğin yaşam doyumunu açıklamasına ilişkin hesaplanan beta $(\beta)$ katsayıs1 -,26 iken; genel affetme modele dâhil edildiğinde -,18'e gerilemiştir. Beta $(\beta)$ değerindeki bu azalmanın anlamlı olup olmadığının belirlenmesi Sobel testi ile incelenmiştir. Yapılan analiz sonucunda genel affetmenin aracılık etkisinin anlamlı olduğu bulunmuştur $(\mathrm{z}=-6,54 ; \mathrm{p}<, 01)$. Sonuç olarak, olumsuz mükemmeliyetçilik ile yaşam doyumu arasındaki ilişkide genel affetmenin kısmi aracı rolünün olduğu belirlenmiştir.

Mükemmeliyetçiliğin diğer boyutu olan olumlu mükemmeliyetçiliğin yaşam doyumunu açıklamasında kendini affetmenin aracı rolünün olup olmadığının belirlenmesinde ilk aşama olarak yapılan çoklu doğrusal regresyon analizine göre olumlu mükemmeliyetçiliğin kendini affetmeyi anlamlı düzeyde yordadığ $1\left(R^{2}=, 008\right.$; $\left.\mathbf{t}_{(403)}=16,192 ; p<, 01 ; \beta=, 09\right)$ ve kendini affetmenin de yaşam doyumunu anlamlı şekilde yordadığ elde edilmiştir $\left(\mathrm{R}^{2}=, 142 ; \mathrm{t}(403)=8,33 ; \mathrm{p}<, 01 ; \beta=, 28\right)$. Çoklu doğrusal regresyon analizi ile ulaşılan bu bulgular, aracilık testi için gerekli olan koşulların sağlandığını göstermiştir. Yapılan analiz sonucunda belirlenen aracılık etkisi Şekil $6^{\prime}$ da sunulmuştur.

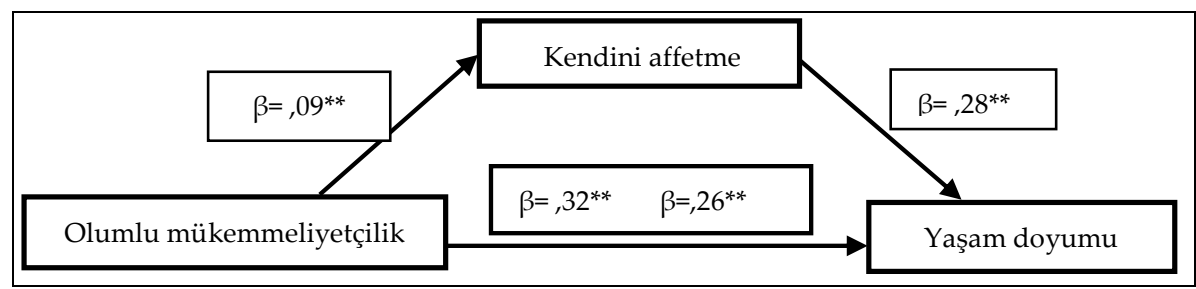

Şekil 6. Özel Gereksinimli Çocuğa Sahip Annelerin Olumlu Mükemmeliyetçilikleri ile Yaşam Doyumları Arasındaki İlişkide Kendini Affetmenin Aracı Rolüne İlişkin Beta Katsayıları

Şekil 6'ya göre olumlu mükemmeliyetçiliğin yaşam doyumunu açıklamasına ilişkin hesaplanan beta ( $\beta$ ) katsayısı ,32 iken; kendini affetme modele dahil edildiğinde ,26'ya gerilemiş̧tir. Beta $(\beta)$ değerindeki bu azalmanın anlamlı olup olmadığının belirlenmesi Sobel testi ile incelenmiştir. Yapılan analiz sonucunda kendini affetmenin aracılık etkisinin anlamlı olduğu bulunmuştur $(\mathrm{z}=-8,82 ; \mathrm{p}<, 01)$. Sonuç olarak, olumlu mükemmeliyetçilik ile yaşam doyumu arasındaki ilişkide kendini affetmenin kısmi aracı rolünün olduğu belirlenmiştir.

Olumlu mükemmeliyetçiliğin yaşam doyumunu açıklamasında başkalarını affetmenin aracı rolünün olup olmadığının belirlenmesinde ilk aşama olarak yapılan çoklu doğrusal regresyon analizine göre olumlu mükemmeliyetçiliğin başkalarını affetmeyi anlamlı biçimde yordamadı $\breve{g}_{1}\left(R^{2}=, 003 ; t_{(403)}=1,074 ; p>05 ; \beta=, 053\right)$ belirlenmiştir. Ulaşılan bu bulgu, aracılık testi için gerekli olan koşulların sağlanmadığını göstermiştir. Bu nedenle olumlu mükemmeliyetçilik ile yaşam doyumu arasındaki ilişkide başkalarını affetmenin aracı rolünün incelenmesine yönelik analizlere geçilememiştir. Sonuç olarak, olumlu mükemmeliyetçilik yaşam doyumunu anlamlı şekilde açıklamadığı için bu iki değişken arasında başkalarını affetmenin aracı rolünün olmadığı belirlenmiştir.

Olumlu mükemmeliyetçiliğin yaşam doyumunu açıklamasında durumu affetmenin aracı rolünün olup olmadığının belirlenmesinde ilk aşama olarak yapılan çoklu doğrusal regresyon analizine göre olumlu 
mükemmeliyetçiliğin durumu affetmeyi anlamlı düzeyde açıkladığı $\left(\mathrm{R}^{2=}=007 ; \mathrm{t}_{(403)}=16,985 ; \mathrm{p}<, 01 ; \beta=, 09\right)$, durumu affetmeni de yaşam doyumunu anlamlı şekilde açıladığı $\left(R^{2}=, 117 ; t(403)=8,123 ; p<, 01 ; \beta=, 42\right)$ saptanmıştır. Çoklu doğrusal regresyon analizi ile ulaşılan bu bulgular, aracilık testi için gerekli olan koşulların sağlandığını göstermiştir. Yapılan analiz sonucunda belirlenen aracılık etkisi Şekil 7'de sunulmuştur.

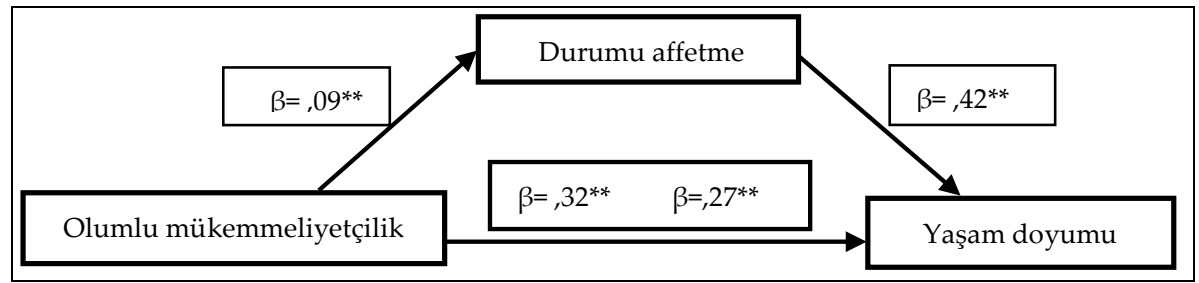

Şekil 7. Özel Gereksinimli Çocuğa Sahip Annelerin Olumlu Mükemmeliyetçilikleri ile Yaşam Doyumları Arasındaki İlişkide Durumu Affetmenin Aracı Rolüne İlişkin Beta Katsayıları

Şekil 7'ye göre olumlu mükemmeliyetçiliğin yaşam doyumunu açıklamasına ilişkin hesaplanan beta $(\beta)$ katsayısı ,32 iken; durumu affetme modele dahil edildiğinde ,27'e gerilemiştir. Beta $(\beta)$ değerindeki bu azalmanın anlamlı olup olmadığının belirlenmesi Sobel testi ile incelenmiştir. Yapılan analiz sonucunda durumu affetmenin aracılık etkisinin anlamlı olduğu bulunmuştur $(\mathrm{z}=-7,32 ; \mathrm{p}<, 01)$. Sonuç olarak, olumlu mükemmeliyetçilik ile yaşam doyumu arasındaki ilişkide durumu affetmenin kısmi aracı rolünün olduğu belirlenmiştir.

Olumlu mükemmeliyetçiliğin yaşam doyumunu açıklamasında genel affetmenin aracı rolünün olup olmadığının belirlenmesinde ilk aşama olarak yapılan çoklu doğrusal regresyon analizine göre olumlu mükemmeliyetçiliğin genel affetmeyi anlamlı düzeyde yordadığ $\left(\mathrm{R}^{2}=, 008 ; \mathrm{t}(403)=18,594 ; \mathrm{p}<, 01 ; \beta=, 09\right)$ ve genel affetmenin de yaşam doyumunu anlamlı şekilde yordadığı elde edilmiştir $\left(R^{2}=, 121 ; t_{(403)}=6,676 ; p<, 01 ; \beta=, 34\right)$. Çoklu doğrusal regresyon analizi ile ulaşılan bu bulgular, aracılık testi için gerekli olan koşulların sağlandığını göstermiştir. Yapılan analiz sonucunda belirlenen aracllı etkisi Şekil 8'de sunulmuştur.

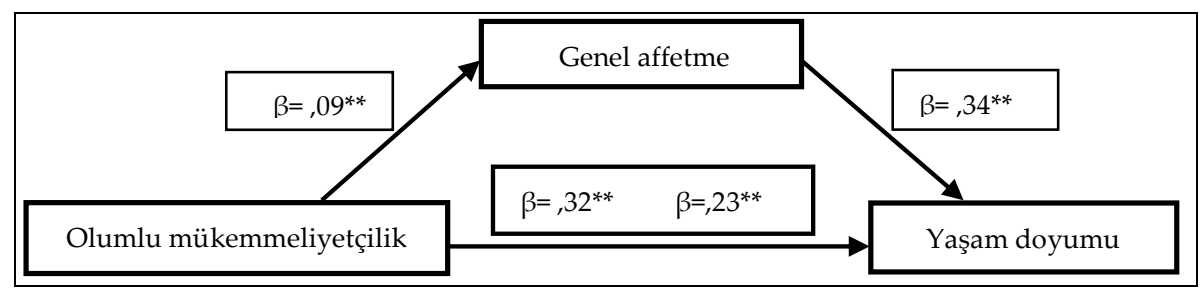

Şekil 8. Özel Gereksinimli Çocuğa Sahip Annelerin Olumlu Mükemmeliyetçilikleri ile Yaşam Doyumları Arasındaki İlişkide Genel Affetmenin Aracı Rolüne İlişkin Beta Katsayıları

Şekil 8'e göre olumlu mükemmeliyetçiliğin yaşam doyumunu açıklamasına ilişkin hesaplanan beta $(\beta)$ katsayıs1 ,32 iken; genel affetme modele dahil edildiğinde ,23'e gerilemiştir. Beta ( $\beta$ ) değerindeki bu azalmanın anlamlı olup olmadığının belirlenmesi Sobel testi ile incelenmiştir. Yapılan analiz sonucunda genel affetmenin aracılık etkisinin anlamlı olduğu bulunmuştur $(\mathrm{z}=-6,28 ; \mathrm{p}<, 01)$. Sonuç olarak, olumlu mükemmeliyetçilik ile yaşam doyumu arasındaki ilişkide genel affetmenin kısmi aracı rolünün olduğu belirlenmiştir.

\section{Sonuç ve Tartışma}

Bu bölümde araştırmanın sonuçlarının tartışılmasına ve literatürle ilişkilendirilerek yorumlanmasına yer verilmiştir. Bu bölümün takip edilebilmesini kolaylaştırmak amacıyla araştırmanın alt amaçlarına ilişkin elde edilen sonuçlar ve bu sonuçlara yönelik yapılan tartışmalar sırasıyla sunulmuştur.

$\mathrm{Bu}$ araştırmada özel gereksinimli çocuğa sahip annelerin mükemmeliyetçilikleri ile yaşam doyumları arasındaki ilişkide affetmenin aracı rolü incelenmiş ve yapılan analizler sonucunda mükemmeliyetçiliğin affetme aracılığıyla yaşam doyumunu anlamlı şekilde açıkladığı bulunmuştur. Diğer bir deyişle özel 
gereksinimli çocuğa sahip annelerin mükemmeliyetçilikleri ile yaşam doyumları arasındaki ilişkide affetmenin kısmi aracı değişken olarak rol oynadığı belirlenmiştir. Elde edilen bu sonuçlar ve bu sonuçlara ilişkin yapılan yorumlar aşağıda ayrıntılı şekilde sunulmuştur.

Araştırmadan elde edilen sonuçlara göre özel gereksinimli çocuğa sahip annelerin olumsuz mükemmeliyetçilikleri kendini affetme, başkalarını affetme, durumu affetme ve genel affetme davranışlarını negatif yönde açıklamaktadır. Bununla birlikte özel gereksinimli çocuğa sahip annelerin olumlu mükemmeliyetçilikleri kendini affetme, durumu affetme ve genel affetme davranışlarını pozitif yönde açıklamaktadır. Bu sonuçlar ile ilgili olduğu düşünülen araştırmalar incelendiğinde Kim (2008), yaptığı çalışmasında kendine odaklı, başkalarına odaklı ve sosyal olarak belirlenen mükemmeliyetçiliğin bireylerin kendini affetmesi ve başkalarını affetmesi ile negatif yönlü ve anlamlı bir ilişkisinin olduğunu tespit etmiştir. Mistler'in (2010) gerçekleştirdiği çalışmada affetme ve mükemmeliyetçilik arasında negatif yönlü bir ilişki belirlenmiştir. Bugay (2010) ile Kaya ve Peker (2016) çalışmalarında kendini affetmenin mükemmeliyetçilik ile negatif yönlü bir ilişki gösterdiğini öne sürmüştür. Benzer şekilde Camadan ve Yazıcı'nın (2017) araştırmasında da mükemmeliyetçiliğin, affetmenin olumsuz bir yordayıcısı olduğu belirtilmiştir. Elde edilen bu sonuçlar ışığında mükemmeliyetçilik ile affetme arasında negatif yönlü ve anlamlı bir ilişkinin olduğu öne sürülebilir. Ancak değinilen bu araştırmalarda mükemmeliyetçilik olumlu ve olumsuz olarak ele alınmamış, genel olarak incelenmiştir. Ayrıca affetme de tek bir yapı biçiminde ele alınarak değerlendirilmiş ve affetmenin alt boyutlarına ilişkin çıkarımlar ileri sürülmemiştir. Bu araştırmada ise mükemmeliyetçilik olumlu ve olumsuz boyutları ile affetme de boyutları ve geneli dikkate alınarak incelenmiştir. Araştırmada mükemmeliyetçiliğin özellikle olumlu alt boyutunun affetmeye pozitif yönde bir katkı sağladığı, diğer deyişle özel gereksinimli çocuğa sahip annelerin olumlu mükemmeliyetçilikleri arttıkça daha affedici oldukları belirlenmiştir. Araştırmada olumlu mükemmeliyetçiliğin sadece başkalarını affetme boyutu üzerinde anlamlı düzeyde bir etkisinin olmadığı bulunmuştur. Bunun yanında özel gereksinimli çocuğa sahip annelerin olumsuz mükemmeliyetçi olma durumlarında ise affetmenin geneli ve tüm boyutlarının azaldığı ortaya konulmuştur.

Slade ve Owens'e (1998) göre olumlu mükemmeliyetçilik, bireyin yüksek standartlar çerçevesinde belirlediği hedeflerini ve amaçlarını elde edebilmek üzere sürdürmekte olduğu girişim olarak tanımlanırken, olumsuz mükemmeliyetçilik ise bireyin, başkalarının kendisinden yüksek beklentiler içerisinde olduğunu düşünmesi ve hoşnutsuzluk ile nevrotik duygulara yönelmesi şeklinde açıklanmıştır. Schuler'e (2000) göre olumlu mükemmeliyetçiliğe sahip bireyler, davranışlarında düzenlilik ararlar ve başarısızlıkla sonuçlanan durumlara karşı aşırı sert bir tutum içerisinde olmazlar. Kottman'a (2000) göre ise olumlu mükemmeliyetçi bireyler, yüksek standart içerikli öğelere sahip olabilmek amacıyla aşırı derecede kaygılanmazlar ve belirlemiş oldukları hedeflere varamadıklarında hevesleri sona ermez, daha akıllıca ve sıkıca çalışma konusunda motive olurlar. Buna karşın olumsuz mükemmeliyetçi bireyler ise kendileri için tespit ettikleri yüksek standart içerikli öğelere sahip olmak için oldukça fazla kaygılıdırlar ve mükemmel hedefe varamadıklarında kendilerini tümüyle bitmişs şekilde hissederler.

Yukarıdaki açıklamalara dayanarak olumsuz mükemmeliyetçiliğin, özel gereksinimli çocuğa sahip annelerin çeşitli sorunlar yaşamasına neden olabileceği anlaşılmaktadır. Olumlu mükemmeliyetçilikte ise sert tutumlar gösterme, kendini suçlama, hatalarını ön plana çıkarma ve affedememe gibi sonuçların pek bulunmadığı anlaşılmaktadır. Nitekim bu araştırmada elde edilen sonuçlara göre olumlu mükemmeliyetçi özelliklere sahip olan anneler daha fazla affedici özellikler gösterebilmektedirler. Hamachek'e (1978) göre normal mükemmeliyetçi bireyler, gereğinden çok girişim göstererek kendilerini sonunda mutlu edecek bir ürüne ulaşmaya çalışırken, olumsuz mükemmeliyetçi bireyler ise yerine getirdikleri sorumluluğun çok da yeterli olmadığına inandıklarından çoğunlukla mutlu olamamaktadırlar. Değinilen bilgilerden hareketle, özel gereksinimli çocuğa sahip annelerin mükemmeliyetçiliklerinin olumlu yönde olmasının, kendilerine ve yaşadıkları durumlara yönelik olumsuz duygulardan vazgeçerek affetme davranışlarının ön planda olmasını sağladığı söylenebilir. Öte yandan özel gereksinimli çocuğa sahip bir annenin olumsuz mükemmeliyetçi bir eğilim içerisinde olması, çocuğunun özel gereksinimli olması ile ilgili olarak kendini affedememesi, sorumlu 
tutması ve suçlaması ile sonuçlanabilir. Bu da yaşama yönelik negatif düşünce ve duygular geliştirmesine yol açabilmektedir.

Araştırmadan elde edilen sonuçlara göre özel gereksinimli çocuğa sahip annelerin olumlu mükemmeliyetçilikleri yaşam doyumlarını pozitif yönde açıklamaktadır. Bununla birlikte özel gereksinimli çocuğa sahip annelerin olumsuz mükemmeliyetçilikleri yaşam doyumlarını negatif yönde açıklamaktadır. Bu sonuçlar ile ilgili olduğu düşünülen araştırmalar incelendiğinde Karababa'nın (2012) çalışmasında olumlu mükemmeliyetçiliğin, yaşam doyumunu olumlu yönde yordadığı; olumsuz mükemmeliyetçiliğin ise yaşam doyumunu anlamlı şekilde yordamadığı sonucuna ulaşılmıştır. Çalışandemir ve Tagay (2015) araştırmasında çevresindekilerin yapabileceklerine dair duyulan inanç ve beklentileri içeren başkalarına yönelik mükemmeliyetçiliğin, yaşam doyumunu olumlu yönde yordadığı belirlenmiştir. Öte yandan Thompson ve diğerleri (2005), olumlu mükemmeliyetçilik puanlarının yaşam doyumu üzerinde anlamlı bir etkisinin olmadığını ileri sürmüştür. Benzer şekilde Karababa ve Acun Kapıkıran (2014) tarafından olumsuz mükemmeliyetçiliğin yaşam doyumunu anlamlı şekilde yordamadığı saptanmıştır. Adler'e (2004) göre olumsuz mükemmeliyetçilerde üst düzeyde kurdukları hedeflerine varma konusunda "ya hep ya hiç" tarzı anlayış baskındır, geliştirdikleri çözüm önerileri düşük düzeydedir ve rast geldikleri problemler onlar açısından oldukça ağır yükümlülüktür. Özel gereksinimli çocuğa sahip annelerin olumsuz mükemmeliyetçilikleri arttıkça çocuklarının gelişimlerinde kusursuzluk, ilerleme ve normalleşmeye odaklandıklarından zaman içerisinde kendilerine yönelik affetme düzeylerinde de azalma yaşanmaktadır. Günlük yaşamları içerisinde çocuklarına yönelik herhangi bir sorumluluğu yerine getiremediklerinde de kendilerini suçlayabilmektedirler. Dolayısıyla bu süreç, annelerin yaşam kalitesini ve yaşam doyumunu düşürebilmektedir. Bu kapsamda özel gereksinimli çocuğa sahip anneler, çocukları ile ilgili mükemmeli yakalamak için günlük hayatlarının normal akışını değiştirme çabasına girdiklerinde yaşamdan aldıkları doyum düzeyi düşebilmektedir. Bu bağlamda özel gereksinimli bireylerin gelişimsel özellikleri dikkate alındığında bazen meydana gelen geriye gitme veya yerinde sayma durumlarında da annelerin yaşam doyumlarının azalabildiği söylenebilir. Olumsuz mükemmeliyetçi özellik geliştiren anneler, kendileri açısından gerçekle ilgisi bulunmayan ve elde edilmesi neredeyse olanaksız sayılabilir koşullar tesis etme eğilimine girdiklerinde yaşam doyumlarında azalmalar yaşanabilmektedir. Bu durumun aksine olumlu mükemmeliyetçilik ile ilgili olarak ise Ram (2005), bireyin olumlu mükemmeliyetçilik eğilimi yükseldikçe başarısızlık veya hayal kırıklığı yaşamasının ardından girişimlerini tazeleyebilme, motivasyonlarının azalmaması, hedeflerinden sapmama ve akıllıca önerilerde bulunabilme gibi öğelerin gerçekleşme olasılığının yükseldiğine değinmiştir.

Özel gereksinimli çocuğa sahip annelerde olumsuz mükemmeliyetçiliğin gelişimi, her şeyin en iyisini yapma ve çevresinin de aynı düzeyde yapmasını bekleme şeklinde kendini gösterebilmektedir. Ancak bu annelerin başkalarından beklediği şeyin önemli olduğunu düşünmesi ve istenilen düzeyde yerine getirilmesini beklemesine rağmen beklentilerinin yerine getirilmemesi ise yaşam doyumlarını olumsuz yönde etkileyebilmektedir. Buna karşın olumlu mükemmeliyetçilik duygusu gelişen annelerin ise daha toleranslı ve anlayışlı olduklarından dolayı yaşam doyumları bu doğrultuda artış gösterebilmektedir. Enns, Cox ve Clara (2002) da yüksek düzeyde olumlu mükemmeliyetçiliği olan bireylerin artan girişimleri ile beraber sonunda istenen amaca varılamamış olunsa bile tatmin olma duygusu yaşadıklarına dikkat çekmiştir. Olumlu mükemmeliyetçiliği bünyelerinde inşa eden anneler kendilerinin ve yeterliklerinin farkında olduklarından ön gördükleri standart koşullar da bu yönde daha gerçekçi ve elde edilebilir nitelikte olabilmektedir. Dolayısıyla bu annelerin standartlarını giderebilme ve davranışlarına yansıtabilme olasılıkları da daha fazla olabilmektedir. Öte yandan özel gereksinimli bir çocuğa sahip olan annenin, olumsuz mükemmeliyetçiliğin etkisi ile kendisinden ve etrafından yüksek ve gerçekçi olmayan beklentiler geliştirmesi, özel bir çocuğa sahip olmasının doğuracağı çeşitli sınırlılıklar nedeniyle kendisini daha fazla olumsuz yönde etkileyebilecektir. Bu sınırlılıklar annenin kendisinin yapabilecekleri ile ilgili olabileceği gibi özel gereksinimli çocuğunun yapabilecekleri ile ilgili de olabilir. Sonuçta tüm öne sürülen ifadeler değerlendirildiğinde özel gereksinimli bir çocuğa sahip annenin olumsuz mükemmeliyetçi eğilimleri ile yaşam doyumu arasında bu noktada olumsuz yönlü bir ilişkinin olduğu söylenebilir. 
Araştırmadan elde edilen sonuçlara göre özel gereksinimli çocuğa sahip annelerin kendini affetme, başkalarını affetme, durumu affetme ve genel affetme davranışları yaşam doyumlarını olumlu yönde açıklamaktadır. Bu sonucu destekler yönde Thompson ve diğerlerinin (2005) yaptığı çalışmada durumu affetmenin yaşam doyumu ile pozitif yönlü ilişkili olduğu sonucuna ulaşılmıştır. Benzer şekilde Öztörel'in (2018) çalışmasında yaşam doyumu ile affetmenin geneli ve alt boyutları olan kendini affetme, başkalarını affetme ve durumu affetme arasında anlamlı ve olumlu yönlü ilişkilerin olduğu tespit edilmiştir. Zhu'nun (2015) yapmış olduğu araştırmada, sosyal destek ve dengeli duygulanımın aracı etkisi yoluyla affetmenin yaşam doyumu üzerinde dolaylı bir etkisinin bulunduğu tespit edilmiştir. Ayten (2014), Ayten ve Ferhan (2016), Ayten ve Gashi (2012), Egan ve Todorov (2009), Macaskill (2012), Toussaint ve Friedman (2009) ile Webb, Dula ve Brewer (2012) tarafından yapılan araştırmalarda da affetmenin yaşam doyumu üzerinde olumlu etkilerinin olduğu belirlenmiştir.

Yukarıda değinilen araştırmalar ile bu araştırmadaki sonuçlara dayanarak özel gereksinimli çocuğa sahip annelerin affetme eğilimlerinin artışının, onların yaşam doyumlarını da artırdığı değerlendirmesine varılabilir. Fışıloğlu ve Fışıloğlu (1997), sağlıklı bir çocuğa sahip olma beklentisi içindeki ebeveynin, özel gereksinimli bir çocuğa sahip olduğu gerçeğiyle karşılaştığında uzun süreli bir yas sürecine girebildiğini öne sürmüşlerdir. Cameron, Dobson ve Day'a (1991) göre annelerin bir bölümü bu süreçte şok olmakta, inancını kaybetmekte, reddedici, sinirli ve kendilerini suçlayıcı olabilmekte, bazıları ise korku, kayıp duygusu ve kızgınlık hissetmekte ve kendilerini affedememektedir. Deniz ve diğerlerine (2009) göre ise normal gelişim gösteren bir çocuk, “Bakın, ne kadar iyiyim!” mesajını çevreye iletirken, özel gereksinimli bir çocuk "Başaramadım, iyi değilim!" mesajıyla annede mutsuzluk ve hayal kırıklığı ile başarısızlık duygularına yol açabilmektedir. Dolayısıyla gerek kendilerini gerekse çevrelerini affedici bir tavır içerisinde olabilen annelerin özel gereksinimli bir çocuğa sahip olmaları durumunda gelişen olumsuz duyguları daha az yaşamalarına katkı sağlayabileceği öngörülmüştür. Öte yandan affedici olmayan davranışlarının ise özel gereksinimli bir çocuğa sahip olmaları durumunda kendilerini ve çevrelerini daha fazla suçlamalarına ve bunun da yaşam doyumlarını olumsuz yönde etkilemesine neden olabileceği değerlendirilmiştir.

Araştırmadan elde edilen sonuçlara göre özel gereksinimli çocuğa sahip annelerin özel gereksinimli çocuğa sahip annelerin olumsuz mükemmeliyetçilikleri ile yaşam doyumları arasındaki ilişkide kendini affetme, başkalarını affetme, durumu affetme ve genel affetmenin aracı rolü anlamlıdır. Bununla birlikte özel gereksinimli çocuğa sahip annelerin olumlu mükemmeliyetçilikleri ile yaşam doyumları arasındaki ilişkide kendini affetme, durumu affetme ve genel affetmenin aracı rolü anlamlıdır. Bu sonuçlara göre annelerin olumlu ve olumsuz mükemmeliyetçilikleri affetme ve yaşam doyumu ile affetmeleri de yaşam doyumu ile anlamlı ilişkilere sahiptir. Bu sonuçlara ilişkin ulaşılan temel çıkarsama, özel gereksinimli çocuğa sahip olma durumu, annelerin çoğunlukla kendini suçlama, hayal kırıklığı, pişmanlık ve umutsuzluk gibi olumsuz hisler yaşamasına neden olabilmektedir. Nitekim bu konuyla ilgili olarak Çelik ve diğerlerinin (2014) belirttiği üzere bireylerin, mükemmeliyetçiliğin olumsuz boyutuna ilişkin eğilimleri arttıkça affetmeleri ve yaşam doyumları da olumsuz yönde değişmektedir. Sen ve Yurtsever (2007) ile Koçan'a (2013) göre engellilik, sadece özel gereksinimli çocuğu değil, aileyi de sosyal, fiziksel ve duygusal yönden etkileyip çok boyutlu zorluklarla karşılaşmalarına yol açabilmektedir. Engel düzeyi ve türü ne olursa olsun özel gereksinimli çocuğa sahip anneler için bu durum travmatik bir olgu olabilmektedir. Bahar, Bahar, Savaş ve Parlar (2009), Cangür ve diğerleri (2013) ile Fırat, Diler, Avcı ve Şeydaoğlu (2002) tarafından ileri sürüldüğü üzere yaşanan bu gibi durumlar ve annenin yaşadığı suçluluk hissi, kendisini depresyona sürükleyebilmektedir. Bu sonuçlara dayanarak özel gereksinimli çocuğa sahip annelerin mükemmeliyetçilikleri ve affetme eğilimlerinin, yaşam doyumları açısından önemli olduğu anlaşılmıştır. Bir annenin özel gereksinimli çocuğa sahip olması durumunda olumsuz mükemmeliyetçi eğilimler geliştirmesi yaşam doyumunu olumsuz yönde etkileyebildiği, ancak bu süreçte affetme davranışı geliştirebilmesi halinde yaşam doyumunun bundan daha az etkilendiği söylenebilir. Bu açıklamalardan hareketle annelerin olumlu mükemmeliyetçiliklerini artırıcı, olumsuz mükemmeliyetçiliklerini azaltıcı, kendilerini, başkalarını ve durumu affedici davranışlarını artırıcı içerikli müdahale programlarının hazırlanmasının ve uygulanmasının yaşam doyumları açısından yararlı olabileceği düşünülmektedir. 
$\mathrm{Bu}$ araştırmanın birtakım sinırlılıkları söz konusudur. Bunlardan birisi veri toplama sürecinde yalnızca nicel veri toplama tekniklerine başvurulmuş olmasıdır. İleride yapılacak araştırmalarda nitel veri toplama tekniklerinin de kullanılması derinlemesine analiz yapma imkânı sağlayabilecektir. Araştırmada karşılaşılan diğer bir sınırlılık, verilerin sadece özel gereksinimli çocuğa sahip annelerden toplanmış olmasıdır. Babaların çoğunluğunun çalışmaya katılmak istememesinden dolayı çalışmanın amaç ve kapsamı sadece annelerle ilgili olacak şekilde sınırlandırılmıştır. Ayrıca annelerin çalışmaya katılım göstermesi için de büyük bir çaba sarf edilmiş ve sadece katılmaya isteklilik gösterenler çalışmaya dâhil edilmiştir. Bu nedenle ileride yapılacak çalışmalarda uygulanan yazılı formların yanı sıra hem annelerin hem de babaların çalışmaya daha fazla katılımcı olabilmelerini sağlamak amacıyla farklı veri toplama yolları da geliştirilebilir ve uygulanabilir. Bu araştırma kapsamında özel gereksinimli çocuklardan herhangi bir veri toplanmamıştır. Yapılacak çalışmalarda çocuklardan da veri toplanarak annelerinin yaşam doyumları ile çocuklarının yaşam doyumları arasındaki ilişkiler de incelenebilir. Bununla birlikte ileride yapılacak araştırmalarda mükemmeliyetçilik ile yaşam doyumu arasında affetme dışında aracı etkisi olabilecek farklı değişkenler (özyeterlik, empati, benlik saygısı) işe koşulabilir. Buna ek olarak affetme, yaşam doyumu ve mükemmeliyetçilik arasındaki ilişkiyi inceleyen farklı gruplar üzerinde çalışmalar da yapılabilir. Bu kapsamda farklı paydaşlardan (özel gereksinimli çocuğa sahip babalar, özel eğitim öğretmenleri, özel eğitim kurumlarının yöneticileri vb.) da ilgili değişkenlere yönelik veriler toplanabilir. Özel gereksinimli çocuğa sahip anneler ile yapılacak rehberlik ya da psikolojik danışma çalışmalarında araştırmadan elde edilen sonuçlardan yararlanılmasının da etkili olacağı değerlendirilmektedir. Bu kapsamda özel gereksinimli annelerin yaşam doyumlarının artırılmasına yönelik yapılacak faaliyetlerde bu bireylerin olumsuz mükemmeliyetçiliklerini azaltıcı, olumlu mükemmeliyetçiliklerini ve affetme davranışlarını artırıcı içerik ve etkinliklere yer verilmesinin yerinde olacağı düşünülmektedir.

\section{Yazar(lar)in Beyanı}

Araştırmacıların katkı oranı beyanı: Araştırmanın verileri doğrudan birinci yazar tarafından toplanmıştır. Her iki yazar, araştırmanın giriş, yöntem, bulgular, sonuç ve tartışma bölümlerine katkıda bulunmuştur. Araştırmaya birinci yazar $\% 60$, ikinci yazar $\% 40$ oranında katkı sunduklarım beyan etmektedirler.

Çatışma beyanı: Araştırmada, yazarların kendi içinde ve diğer kişi/kurum/kuruşlarla herhangi bir çıkar çatışması söz konusu değildir.

Destek ve teşekkür: Bu araştırmanın yürütülmesi sürecinde herhangi bir destek alınmamıştır.

\section{Kaynaklar}

Adler, A. (2004). Yaşamın anlam ve amacı (7. bs.) (Çev. Kamuran Şipal). İstanbul: Say Yayınları.

Adler, A. (2008). İnsanı tanıma sanatı (Çev. Kamuran Şipal). İstanbul: Say Yayınları

Akandere, M., Acar. M. ve Baştuğ, G. (2009). Zihinsel ve fiziksel engelli çocuğa sahip anne ve babaların yaşam doyumu ve umutsuzluk düzeylerinin incelenmesi. Selçuk Üniversitesi Sosyal Bilimler Enstitüsü Dergisi, 22(1), 23-32.

Altay, B. ve Avcı, İ. A. (2009). Huzurevinde yasayan yaşlılarda özbakım gücü ve yasam doyumu arasındaki ilişki. Dicle Tip Dergisi, 36(4), 275-282.

Altuğ Özsoy, S., Özkahraman, Ş. ve Çallı, F. (2006). Zihinsel engelli çocuk sahibi ailelerin yaşadıkları güçlüklerin incelenmesi. Aile ve Toplum, 3(9), 69-77.

Avşaroğlu, S., Deniz, M. E. ve Kahraman, A. (2005). Teknik öğretmenlerde yaşam doyumu iş doyumu ve mesleki tükenmişlik düzeylerinin incelenmesi. Selçuk Üniversitesi Sosyal Bilimler Enstitüsü Dergisi, 14, 115-129.

Ayten, A. (2014). Din ve sağlık: Bireysel dindarlık, sağlık davranışları ve hayat memnuniyeti ilişkisi üzerine bir araştırma. Din Bilimleri Akademik Araştırma Dergisi, 13(3), 7-31. 
Ayten, A. ve Ferhan, H. (2016). Forgiveness, religiousness, and life satisfaction: An empirical study on Turkish and Jordanian university students. Spiritual Psychology and Counseling, 1(1), 79-84.

Ayten, A. ve Gashi, F. (2012). Affetme ve hayat memnuniyeti üzerine karşılaştırmalı bir araştırma. Balkan Araştırmaları Dergisi, 3(2), 11-36.

Ayyıldız, T., Konuk Şener, D., Kulakçı, H. ve Veren, F. (2012). Zihinsel engelli çocuğa sahip annelerin stresle baş etme yöntemlerinin değerlendirilmesi. Ankara Sağlık Hizmetleri Dergisi, 11(2), 1-12.

Bahar, A., Bahar, G., Savaş, H. A. ve Parlar, S. (2009). Determining the ways of coping with stress with depression and anxiety levels of the mothers of handicapped children. Firat Health Services Journal, 4(11), 97-112.

Baron, R. M. ve Kenny, D. A. (1986). The moderator-mediator variable distinction in social-psychological research: Conceptual, strategic and statistical considerations. Journal Personal Social Psychology, 51, 117382.

Beutel, M. E., Glaesmer, H., Wiltink, J., Marian, H. ve Brähler, E. (2010). Life satisfaction, anxiety, depression and resilience across the life span of men. The Aging Male, 13(1), 32-39.

Bowman, R. A. (2001). Quality of life assessment for young children with developmental disabilities and their families: Development of a quality of life questionnaire (Doctoral dissertation). Virginia University, Morgantown, WV.

Brown, R. I., MacAdam-Crisp, J., Wang, M. ve Iarocci, G. (2006). Family quality of life when there is a child with a developmental disability. Journal of Policy and Practice in Intellectual Disabilities, 3(4), 238-245.

Bugay, A. (2010). Investigation of social-cognitive, emotional and behavioral variables as predictors of self-forgiveness (Yayınlanmamış doktora tezi). ODTÜ, Ankara.

Bugay, A. ve Demir, A. (2010). A Turkish version of Heartland Forgiveness Scale. Procedia-Social and Behavioral Sciences, 5, 1927-1931.

Bugay, A., Demir, A. ve Delevi, R. (2012). Assessment of the reliability and validity of the Turkish version of Heartland Forgiveness Scale. Psychological Reports, 111(2), 575-584.

Camadan, F. ve Yazıcı, H. (2017). Üniversite öğrencilerinde gözlenen saldırganlık eğilimlerinin açıklanmasına dönük bir model. Hacettepe Üniversitesi Eğitim Fakültesi Dergisi, 32(2), 343-360.

Cameron, S. J. ve Armstrong, S., M. (1991). Stress, coping, and resources in mothers of adults with developmental disabilities. Counselling Psychology Quarterly, 4(4), 301-310.

Cameron, S. J., Dobson, L. A. ve Day, D. M. (1991). Stress in parents of developmentally delayed and nondelayed preschool children. Canada's Mental Health, 39(1), 13-17.

Cangür, Ş., Civan, G., Çoban, S., Koç, M., Karakoç, H. ve Budak, S. (2013). Düzce ilinde bedensel ve/veya zihinsel engelli bireylere sahip ailelerin toplumsal yaşama katılımlarının karşılaştırmalı olarak değerlendirilmesi. Düzce Üniversitesi Sağlık Bilimleri Enstitüsü Dergisi, 3(3), 1-9.

Cin, A. (2001). Grup rehberliğinin özürlü çocuğu olan anne babaların kaygı düzeylerinin azaltılmasındaki etkisi (Yayınlanmamış yüksek lisans tezi). İnönü Üniversitesi, Malatya.

Cin, A. ve Kılıç, M. (2005). Deneysel olarak sınanmış grupla psikolojik danışma ve rehberlik programları. S. Erkan ve A. Kaya (Ed.), Özürlü çocuğu olan anne babaların kaygı düzeylerini azaltmaya yönelik bir grup rehberliği uygulaması (s. 70-102) içinde. Ankara: Pegem-A Yayıncılık.

Craddock, A. E., Church, W., Harrison, F. ve Sands, A. (2010). Family of origin qualities as predictors of religious dysfunctional perfectionism. Journal of Psychology and Theology, 38(3), 205-214.

Çalışandemir, F. ve Tagay, Ö. (2015). Multidimensional perfectionism and humor styles the predictors of life satisfaction. Procedia- Social and Behavioral Sciences, 174, 939-945. 
Çeçen, A. R. (2008). Üniversite öğrencilerinde yaşam doyumunu yordamada bireysel bütünlük duygusu, aile bütünlük duygusu ve benlik saygısı. Eğitimde Kuram ve Uygulama, 4(1), 19-30.

Çelik, E., Arıcı Özcan, N. ve Turan, M. E. (2014). Ergenlerin yaşam doyumunu algılanan okul yetersizliğinin, sosyal kaynaklı mükemmeliyetçiliğin ve kendini değerlendirmenin yordaması. Eğitimde Kuram ve Uygulama, 10(4), 1143-1155.

Dağlı, A. ve Baysal, N. (2016). Yaşam Doyumu Ölçeğinin Türkçe'ye uyarlanması: Geçerlik ve güvenirlik çalışması. Elektronik Sosyal Bilimler Dergisi, 15(59), 1250-1262.

Davis, D. E., Worthington, E. L., Hook, J. N. ve Hill, P. C. (2013). Research on religion/spirituality and forgiveness: A meta-analytic review. Psychology of Religion and Spirituality, 5(4), 233-241.

Demirel, S. ve Canat, S. (2004). Ankara'daki beş eğitim kurumunda kendini yaralama davranışı üzerine bir çalışma. Kriz Dergisi, 12(3), 1-9.

Deniz, M. E., Dilmaç, B. ve Arıcak, O. T. (2009). Engelli çocuğa sahip olan ebeveynlerin durumluk-sürekli kaygı ve yaşam doyumlarının incelenmesi. Uluslararası İnsan Bilimleri Dergisi, 6(1), 953-968.

Diener, E. (1984). Subjective well-being. Psychological Bulletin. 95(3), 542-575.

Diener, E., Emmons, R. A., Larsen, R. J. ve Griffin, S. (1985). The satisfaction with life scala. Journal of Personality Assessment, 49(1), 71-75.

Egan, L. A. ve Todorov, N. (2009). Forgiveness as a coping strategy to allow school students to deal with the effects of being bullied: Theoretical and empirical discussion. Journal of Social and Clinical Psychology, 28(2), 198-222.

Enns, M. W., Cox, B. J. ve Clara, I. (2002). Adaptive and maladaptive perfectionism: Developmental origins and association with depression proneness. Personality and Individual Differences, 33(6), 921-935.

Enright, R. D. ve Coyle, C. T. (1998). Researching the process model of forgiveness within psychological interventions. E. L. Worthington (Ed.). Dimensions of forgiveness: Psychological research and theological perspectives (s. 139-161) içinde. Philadelphia: Templeton Foundation Press.

Enright, R. D. ve Group, T. H. (1996). Counseling within the forgiveness triad: On forgiving, receiving forgiveness and self-forgiveness. Counseling and Values, 40(2), 107-126.

Enright, R. D., Santos, M. J. D. ve Al-Mabuk, R. (1989). The adolescent as forgiver. Journal of Adolescence, 12(1), 95-110.

Enright, R. D. ve The Human Development Study Group (1994). Piaget on the moral development of forgiveness: Identity or reciprocity? Human Development, 37(2), 63-80.

Ergüner-Tekinalp, B. ve Terzi, Ş. (2012). Terapötik bir araç olarak bağışlama: İyileştirici etken olarak bağışlama olgusunun psikolojik danışma sürecinde kullanımı. Eğitim ve Bilim, 37(166), 14-24.

Ersanll, K. ve Kutlu, M. (1998, Eylül). Zihinsel engelli çocuğu olan annelerin umutsuzluk düzeyleri. VII. Ulusal Eğitim Bilimleri Kongresi'nde sunulan bildiri, Selçuk Üniversitesi, Eğitim Fakültesi, Konya.

Ersoy, Ö. ve Güneysu, S. (1998). Destekleyici eğitim programlarının engelli çocuğu olan anneler üzerindeki etkisi. Ankara: Konak Kırtasiye Yayınları.

Firat, S., Diler, R. S., Avcl, A. ve Şeydaoğlu, G. (2002). Comparison of psychopathology in the mothers of autistic and mentally retarded children. Jounal Korean Medical Science, 17(5), 679-685.

Fışıloğlu, A. ve Fışıloğlu, H. (1997). İşitme engelli birey ile değişim sürecindeki ailelerin karşılaştıkları sorunlar. A. N. Karancı (Ed.), Farklılıkla yaşamak: Aile ve toplumun farklı gereksinimleri olan bireylerle birlikteliği (s. 23-35) içinde. Ankara: Türk Psikologlar Derneği Yayınları. 
Flett, G. ve Hewitt P. L. (2002). Perfectionism in children and their parents, a develepmental analysis perfectionism. G. L. Flett ve P. L. Hewitt (Ed.), Perfectionism: Theory, research, and treatment (s. 89-132) içinde. Washington DC: American Psychological Association.

Gündoğar, D., Gül, S. S., Uskun, E., Demirci, S. ve Keçeci, D. (2007). Üniversite öğrencilerinde yaşam doyumunu yordayan etkenlerin incelenmesi. Klinik Psikiyatri, 10(1), 14-27.

Güvendeğer Doksat, N., Balkanlı Zengin, H. ve Doksat, M. K. (2018). Dikkat eksikliği ve hiperaktivite bozukluğu olan çocukların ebeveynlerinde mükemmeliyetçilik ve dikkat eksikliği ve hiperaktivite bozukluğu. Çukurova Tip Dergisi, 43(3), 581-588.

Hall, J. H. ve Fincham, F. D. (2005). Self-forgiveness: The stepchild of forgiveness research. Journal of Social and Clinical Psychology, 24(5), 621-637.

Hamachek, D. E. (1978). Psychodynamics of normal and neurotic perfectionism. Psychology, 15(1), 27-33.

Headey, B., Kelley, J. ve Wearing, A. (1993). Dimensions of mental health: Life satisfaction, positive affect, anxiety and depression. Social Indicators Research, 29(1), 63-82.

İmamoğlu, A. ve Yavuz, A. (2011). Üniversite gençliğinde dini inanç ve umutsuzluk ilişkisi. Sakarya Üniversitesi İlahiyat Fakültesi Dergisi, 13(23), 205-244.

Jansson-Fröjmark, M. ve Linton, S. J. (2007). Is perfectionism related to pre-existing and future insomnia? A prospective study. British Journal of Clinical Psychology, 46(1), 119-124.

Kaner, S. (2004). Engelli çocukları olan ana-babaların algıladıkları stres, sosyal destek ve yaşam doyumlarının incelenmesi. Ankara Üniversitesi Bilimsel Araştırma Projesi Kesin Raporu. 21.12.2017 tarihinde http://acikarsiv.ankara.edu.tr/browse/498/ adresinden erişildi.

Karababa, A. (2012). Psikolojik danışmanlarda olumlu mükemmeliyetçilik ve olumsuz mükemmeliyetçilik düzeylerinin iş doyumu ve yaşam doyumunu yordamadaki rolü (Yayınlanmamış yüksek lisans tezi). Pamukkale Üniversitesi, Denizli.

Karababa, A. ve Acun Kapıkıran, N. (2014). Psikolojik danışmanlarda olumlu-olumsuz mükemmeliyetçilik düzeylerinin iş ve yaşam doyumunu yordamadaki rolü. Türk Psikolojik Danışma ve Rehberlik Dergisi, 5(42), 138-147.

Kaya, F. ve Peker, A. (2016). Üniversite öğrencilerinin affetme ve mükemmeliyetçilik düzeyleri arasındaki ilişki: Duygusal zekânın aracı rolü. Gaziantep Üniversitesi Sosyal Bilimler Dergisi, 15(4), 1086-1094.

Kırdök, O. (2004). Olumlu ve olumsuz mükemmeliyetçilik ölçeği geliştirme çalışması (Yayınlanmamış yüksek lisans tezi). Çukurova Üniversitesi, Adana.

Kim, L. M. (2008). A perfect storm: Perfectionism, forgiveness, and marital satisfaction (Doctoral dissertation). Available from ProQuest Dissertations and Theses database. (UMI No. 3438546).

Kim, L. M., Johnson, J. L. ve Ripley, J. (2011). A perfect storm: Perfectionism, forgiveness, and marital satisfaction. Individual Differences Research, 9(4), 199-209.

Koçan, S. H. (2013). Engelli çocuğa sahip ebeveynlerin depresyon düzeylerinin incelenmesi. Kastamonu Eğitim Dergisi, 21(2), 589-600.

Kottman, T. (2000). Perfectionist children and adolescents: Implications for school counselors. Professional School Counseling, 3(3), 182-189.

Küçüker, S. (1993). Özürlü çocuk ailelerine yönelik psikolojik danışma hizmetleri. Ankara Üniversitesi Eğitim Bilimleri Fakültesi Özel Eğitim Dergisi, 1(3), 23-29.

Küllü, Z. (2008). Özürlü çocuğa sahip ebeveynlerde depresyon durumunun değerlendirilmesi (Yayınlanmamış yüksek lisans tezi). Erciyes Üniversitesi, Kayseri. 
Lee, J. I., Kim, K. H. ve Oh, S. H. (2003). Depression and life satisfaction of middle-aged man. Korean Journal of Adult Nursing, 15(3), 422.

Leung, J. P. ve Leung, K. (1992). Life satisfaction, self-concept, and relationship with parents in adolescence. Journal of Youth and adolescence, 21(6), 653-665.

Macaskill, A. (2012). Differentiating dispositional self- forgiveness from other-forgiveness: Associations with mental health and life satisfaction. Journal of Social and Clinical Psychology, 31(1), 28-50.

Mahmoud, J. S. R., Staten, R. T., Hall, L. A. ve Lennie, T. A. (2012). The relationship among young adult college students' depression, anxiety, stress, demographics, life satisfaction, and coping styles. Issues in Mental Health Nursing, 33(3), 149-156.

McCullough, M. E. (2001). Forgiveness: Who does it and how do they do it? Current Directions in Psychological Science, 10(6), 194-197.

Milgram, N. A. ve Atzil, M. (1988). Parenting stress in raising autistic children. Journal of Autism and Developmental Disorders, 18(3), 415-424.

Mistler, B. A. (2010). Forgiveness, perfectionism, and the role of self-compassion (Doctoral dissertation). University of Florida, Florida.

Murray, R. J. (2002). Forgiveness as a therapeutic option. The Family Journal: Counseling and Therapy for Couples and Families, 10(3), 315-321.

Özcanarslan, F., Karataş, H. ve Aydın, D. (2014). Şanlıurfa ilinde engelli çocuğa sahip annelerin depresyon durumlarının belirlenmesi. Harran Üniversitesi Tip Fakültesi Dergisi, 11(2), 75-82.

Öztörel, I. (2018). Psikolojik danışman adaylarının psikolojik sağlamlık, yaşam doyumu ve affetme düzeylerinin incelenmesi (Yayınlanmamış yüksek lisans tezi). Yakındoğu Üniversitesi, Lefkoşa.

Pallant, J. (2015). SPSS kullanma kılavuzu (Çev. Sibel, Balcı ve Berat, Ahi.). Ankara: Nobel Yayınları.

Park, J., Turnbull, A. P. ve Rutherford Turnbull, H. (2002). Impacts of poverty on quality of life in families of children with disabilities. Exceptional Children, 68(2), 151-170.

Ram, A. (2005). The relationship of positive and negative perfectionism to academic achievement, achievement motivation and well-being in tertiary students (Master's thesis). University of Canterbury, Christchurch.

Rice, K. G. ve Mirzadeh, S. A. (2000). Perfectionism, attachment and adjustment. Journal of Counseling Psychology, 47(2), 238-250.

Schuler, P. A. (2000). Perfectionism and gifted adolescent. Journal of Secondary Gifted Education, 11(4), 183-196.

Sen, E. ve Yurtsever, S. (2007). Difficulties experienced by families with disabled children. Journal for Specialists in Pediatric Nursing, 12(4), 238-252.

Shin, D. C. ve Johnson, D. M. (1978). Avowed happiness as an overall assessment of the quality of life. Social Indicators Research, 5(1), 475-492.

Singh, K. ve Jha, S. D. (2008). Positive and negative affect, and grit as predictors of happiness and life satisfaction. Journal of the Indian Academy of Applied Psychology, 34(2), 40-45.

Sipos, R., Predescu, E., Muresan, G. ve Iftene, F. (2012). The evaluation of family quality of life of children with autism spectrum disorder and attention deficit hyperactive disorder. Applied Medical Informatics, 30(1), $1-8$.

Slade, P. D. ve Owens, R. G. (1998). A dual process model of perfectionism based on reinforcement theory. Behavior Modification, 22(3), 372-390.

Song, L. ve Appleton, S. (2008). Life satisfaction in urban China: Components and determinants. World Development, 36(11), 2325-2340. 
Tamer, M. (2010). Zihinsel engelli çocuk annelerinde stres yönetimi eğitiminin etkileri (Yayınlanmamış yüksek lisans tezi). Ege Üniversitesi, İzmir.

Thompson, L. Y., Snyder, C. R., Hoffman, L., Michael, S. T., Rasmussen, H. N. ve Billings, L. S. (2005). Dispositional forgiveness of self, others, and situations. Journal of Personality, 73(2), 313-359.

Topbaşoğlu Altan, T. ve Çivitci, A. (2017). Öfke ve yaşam doyumu arasındaki ilişkide affetmenin düzenleyici rolü. Mehmet Akif Ersoy Üniversitesi Sosyal Bilimler Enstitüsü Dergisi, 9(18), 308-327.

Toussaint, L. ve Friedman, P. (2009). Forgiveness, gratitude, and well-being: The mediating role of affect and beliefs. Journal of Happiness Studies, 10(6), 635-654.

Truong, K. T. (1991). Human forgiveness: A phenomenological study about the process of forgiving (Doctoral dissertation). United States International University, San Diego, ABD.

Uz Baş, A. (2011). İlköğretim çağındaki çocuklarda mükemmeliyetçilik boyutları: Kaygı, yaşam doyumu ve akademik başarı ile ilişkileri. Eğitim ve Bilim, 36(162), 261-272.

Ülker Tümlü, G. ve Recepoğlu, E. (2013). Üniversite akademik personelinin psikolojik dayanıklılık ve yaşam doyumu arasındaki ilişki. Yüksekögretim ve Bilim Dergisi, 3(3), 205-2013.

Ünal, S., Karlıdağ, R. ve Yoloğlu, S. (2001). Hekimlerde tükenmişlik ve iş doyumu düzeylerinin yaşam doyumu düzeyleri ile ilişkisi. Klinik Psikiyatri, 4(2), 113-118.

Veenhoven, R. (1996). The study of life satisfaction. W. E. Saris, R. Veenhoven, A. C. Scherpenzeel ve B. Bunting (Ed.), A comparative study of satisfaction with life in europe (s. 11-48) içinde. Budapest: EOtvOs University Press.

Watson, S. M. R. ve Keith, K. D. (2002). Comparing the quality of life of schoolaged children with and without disabilities. Mental Retardation, 40(4), 304-312.

Webb, J. R., Dula, C. S. ve Brewer, K. (2012). Forgiveness and aggression among college students. Journal of Spirituality in Mental Health, 14(1), 38-58.

Yıldırım, F. ve Conk, Z. (2005). Zihinsel yetersizliği olan çocuğa sahip anne babaların stresle başa çıkma tarzlarına ve depresyon düzeylerine planlı eğitime etkisi. Cumhuriyet Üniversitesi Hemşirelik Yüksekokulu Dergisi, 9(2), 1-10.

Yöntem, M. K., Öktem, İ. ve Artuç, S. (2017). Lise öğrencilerinin psikolojik doğum sırasının özgecilik üzerindeki yordayıcı gücünün incelenmesi. Turkish Studies-International Periodical for the Languages, Literature and History of Turkish or Turkic, 12(4), 623-640.

Zhu, H. (2015). Social support and affect balance mediate the association between forgiveness and life satisfaction. Social Indicators Research, 124(2), 1-11. 


\section{EXTENDED ABSTRACT}

\section{Introduction}

This study examined how forgiveness can mediate the relationship between perfectionism and life satisfaction for mothers of children with special needs - who are prone to blaming themselves for the situation they are in. Moreover, those who think that they and their surroundings ought to be perfect tend to seldom be satisfied with their lives. This is where the ability to forgive enters. It is thought that forgiving both of one's self and others might soften this sense perfectionism, and thus boost their level of satisfaction with their lives. In contrast, we believe that opposite might hold true for those [mothers] who constantly blame themselves and have high expectations of their other healthy (non-disabled). In this context, we feel it valuable to put forth just how valuable forgiveness can be in this particular context. Furthermore, no studies examining this interrelationship between forgiveness, perfectionism, and life satisfaction (in a parental context) - or these three elements by themselves, for that matter-exist within this context as of yet either. Therefore, this study intends to close this gap and contribute to the literature.

\section{Method}

The model featured in this study is based on descriptive screening-a method that describes one or more cases without the intervention of the researcher. The study group includes 404 mothers of children special needs, and who happen to receiving support from a special education and rehabilitation centre located in Rize, Turkey. Four data collection instruments were used: (1) A personal information form, (2) The Heartland Forgiveness Scale, (3) The Positive-Negative Perfectionism Scale, and (4) The Life Satisfaction Scale. The researcher was an active officer at the institution, and therefore personally collected the data from the subjects. Our study originally was to include fathers as well; however, their reluctance caused us to shift our focus onto only mothers instead. The data was analysed using multiple regression analysis, Pearson correlation analysis, and the Sobel test. The findings are as follows:

- Perfectionist mothers in the negative sense are unable to forgive themselves, others, and their situation, as well as to forgive in general. Those who are perfectionists in the positive sense likewise have a more positive relationship with forgiveness.

- Mothers who know how to forgive are generally more satisfied with their lives.

- The interrelationship between negative perfectionism, one's sense of life satisfaction, and the ability to forgive is seemingly significant.

- The interrelationship between positive perfectionism, one's sense of life satisfaction, and the ability to forgive is also seemingly significant.

\section{Results}

Our findings reveal that perfectionism (negative and positive), forgiveness, and life satisfaction (for mothers with special needs children) are strongly linked with one another. The main conclusion we can draw from this is that having a child with special needs can send mothers into experiencing self-blame, frustration, regret, and hopelessness. In fact, Çelik, Arıcı Özcan and Turan (2014) indicate that individuals tend to overlook the negative aspect of perfectionism, which in turn negatively affects how satisfied they are with their lives. Sen and Yurtsever (2007) and Koçan (2013) show us that the effects of having disability extends beyond the disabled child themselves into the family on a social, physical, and emotional level. This can be quite traumatic for mother in particular. Bahar, Bahar, Savaş and Parlar (2009), Cangür et al. (2013) and Fırat, Diler, Avcr and Şeydaoğlu (2002) all agree that trauma and guilt and lead the mother to develop depression. Therefore, mothers of children with special needs who are perfectionists in the negative sense are less likely to be satisfied with their lives than those who learn how to forgive.

\section{Conclusion}

We can conclude from our findings that a mother of a special needs child's sense of perfectionism and forgiveness can seriously affect how satisfied they are with their lives either in a positive or negative sense. Furthermore, forgiveness appears to play a mediating role between perfectionism and life satisfaction. 
Accordingly, intervention programs aimed at mothers (parents) that work on strengthening this relationship might very well have a positive impact on their lives in the long run. 